\title{
Article
}

\section{Returnable Transport Packaging in developing countries: drivers, barriers and business performance}

\author{
Yusuf, Yahaya, Olaberinjo, Adebola/E, Papadopoulus, Thanos, \\ Gunasekaran, Angappa, Subramanian, Nachiappan and Sharifi, \\ Hossein \\ Available at http://clok.uclan.ac.uk/15906/ \\ Yusuf, Yahaya ORCID: 0000-0001-6045-3245, Olaberinjo, Adebola/E, \\ Papadopoulus, Thanos, Gunasekaran, Angappa, Subramanian, Nachiappan \\ and Sharifi, Hossein (2017) Returnable Transport Packaging in developing \\ countries: drivers, barriers and business performance. Production Planning \\ and Control, 28 (6-8). pp. 629-658. ISSN 0953-7287
}

It is advisable to refer to the publisher's version if you intend to cite from the work. http://dx.doi.org/10.1080/09537287.2017.1294271

For more information about UCLan's research in this area go to

http://www.uclan.ac.uk/researchgroups/ and search for <name of research Group>.

For information about Research generally at UCLan please go to http://www.uclan.ac.uk/research/

All outputs in CLoK are protected by Intellectual Property Rights law, including Copyright law. Copyright, IPR and Moral Rights for the works on this site are retained by the individual authors and/or other copyright owners. Terms and conditions for use of this material are defined in the policies page. 


\title{
Article
}

\section{Returnable Transport Packaging in developing countries: drivers, barriers and business performance}

\author{
Yusuf, Yahaya, Olaberinjo, Adebola/E, Papadopoulus, Thanos, \\ Gunasekaran, Angappa, Subramanian, Nachiappan and Sharifi, \\ Hossein
}

Available at http://clok.uclan.ac.uk/15906/

Yusuf, Yahaya, Olaberinjo, Adebola/E, Papadopoulus, Thanos, Gunasekaran, Angappa, Subramanian, Nachiappan and Sharifi, Hossein (2016) Returnable Transport Packaging in developing countries: drivers, barriers and business performance. Production Planning and Control. ISSN 0953-7287

It is advisable to refer to the publisher's version if you intend to cite from the work.

For more information about UCLan's research in this area go to http://www.uclan.ac.uk/researchgroups/ and search for < name of research Group>.

For information about Research generally at UCLan please go to http://www.uclan.ac.uk/research/

All outputs in CLoK are protected by Intellectual Property Rights law, including Copyright law. Copyright, IPR and Moral Rights for the works on this site are retained by the individual authors and/or other copyright owners. Terms and conditions for use of this material are defined in the http://clok.uclan.ac.uk/policies/ 


\title{
Returnable Transport Packaging in developing countries: drivers, barriers and business performance
}

Yahaya Y. Yusuf 1 , Adebola E. Olaberinjo², Thanos Papadopoulos ${ }^{3}$, A. Gunasekaran ${ }^{4}$, Nachiappan Subramanian ${ }^{5}$, Hossein Sharifi ${ }^{6}$

\author{
${ }^{1}$ School of Management, University of Central Lancashire, Preston PR1 2HE, UK \\ ${ }^{2}$ ADL Solutions, Admiralty Way, Lekki Phase 1, Lagos, Nigeria \\ ${ }^{3}$ Kent Business School, University of Kent, Canterbury, Kent, CT2 7PE, UK \\ ${ }^{4}$ Charlton College of Business, University of Massachusetts-Dartmouth, MA 02747- \\ 2300, USA
}

5School of Business, Management and Economics, University of Sussex, Brighton BN1 9RH, UK

${ }^{6}$ Management School, University of Liverpool, Liverpool, L69 7ZH, UK

\begin{abstract}
This study, drawing on natural resource-based view (NRBV), identifies drivers, barriers and the potential benefits of Returnable Transport Packaging (RTP) -that is, the repeated use of packaging items- and conceptualises RTP as a technology and resource that supports organisational competitiveness. Specifically, it investigates the impact of RTP adoption on business performance, the effects of drivers, barriers and size of organisations. The data collection took place in Nigeria and South Africa. The findings suggest that RTP has a significant positive impact on business performance. Whilst prior studies seem to suggest that shrinkage and attrition are the major problems identified with the usage of RTP, our findings indicate that there are several other barriers affecting RTP adoption and the resultant performance advantage. The results also show that there is increasing move towards adoption of RTP but some organisations are faced with financial constraints, especially the small and medium size enterprises. In addition, the results show that RTP is largely a 'sustainability facing' initiative with adoptees motivated primarily by potential environmental, economic, social and operational benefits of adoption.
\end{abstract}

Keywords: Reverse logistics, returnable transport packaging, sustainability, business performance, natural resource based view

Corresponding Author: Yahaya Yusuf, email (yyusuf@uclan.ac.uk) 


\title{
Returnable transport packaging in developing countries: drivers, barriers and business performance
}

\begin{abstract}
This study, drawing on natural resource-based view (NRBV), identifies drivers, barriers and the potential benefits of Returnable Transport Packaging (RTP) -that is, the repeated use of packaging items- and conceptualises RTP as a technology and resource that supports organisational competitiveness. Specifically, it investigates the impact of RTP adoption on business performance, the effects of drivers, barriers and size of organisations. The data collection took place in Nigeria and South Africa. The findings suggest that RTP has a significant positive impact on business performance. Whilst prior studies seem to suggest that shrinkage and attrition are the major problems identified with the usage of RTP, our findings indicate that there are several other barriers affecting RTP adoption and the resultant performance advantage. The results also show that there is increasing move towards adoption of RTP but some organisations are faced with financial constraints, especially the small and medium size enterprises. In addition, the results show that RTP is largely a 'sustainability facing' initiative with adoptees motivated primarily by potential environmental, economic, social and operational benefits of adoption.
\end{abstract}

Keywords: Reverse logistics, returnable transport packaging, sustainability, business performance; natural resource based view

\section{Introduction}

Returnable Transport Packaging is part of Reverse Logistics. Reverse Logistics (RL) has recently gained attention in Supply Chain Management (SCM) as the process by which products are returned from consumers for the purpose of gaining their value or planning for their proper disposal (Rogers and Tibben-Lembke, 1999; Dowlatshahi, 2012; Nikolaou et al., 2013). Scholars have identified operational and environmental benefits related to RL (see, Lacerda, 2002; Rogers and Tibben-Lembke, 2001; Chan, 2011; Karia and Wong, 2013), including, among other things, environmental and business performance (e.g. Abdulrahman et al., 2014; Bouzon et al, 2015). RL has been also vital to achieving sustainable supply chains, since it helps in controlling 
waste and maintaining environmental sustainability (Abdallah et al., 2011; Garetti and Taisch, 2012; Huang et al., 2012; Bouzon et al., 2015). Within RL, Returnable Transport Packaging (RTP) reduces or eliminates waste at the final customer, minimises risks to the environment, reduces warehousing costs, and provides workplace efficiency and safety (Silva et al., 2013; RPA, 2016). At the same time, returnable packages may involve higher costs of procurement, transportation, and other costs related to cleaning, repairing, storing, and managing (Zhang et al., 2015). Nevertheless, the drive for the adoption of RTP is as a result of the fast growing social expectations that organizations should create a well-improved business practices and safe working environments by engaging in socially responsible businesses.

Following the Natural-Resource-Based-View (NRBV) (Hart, 1995; Klassen and Whybark, 1999; Vachon and Klassen, 2007; 2008; Hart and Dowell, 2010; Bell et al., 2012; Shi et al., 2012; Jayaram et al., 2015), this research conceptualises RTP as an environmental technology and a esource that limits or reduces "negative impacts of products or services on the natural environment" (Srivastava, 1995: in Klassen and Whybark, 1999: p.599) and subsequently investigates the impact of RTP adoption on business performance, the effects of drivers, barriers and size of organisations, with data drawn from Nigeria and South Africa, the two largest economies in Africa. In comparison to developed countries, there are limited work on RTP in developing countries. Studies have underlined the necessity for developing countries to adopt sustainable practices and as part of such initiatives there is a need for understanding the impact of RTP on business performance in the context of those countries (Sohrabpour et al., 2012; Guarnieri et al., 2015).

The paper is organized as follows: Section 2 discusses the usage of RTP in RL, whereas section 3 presents the tenets of NRBV. Section 4 discusses our conceptual model and hypotheses, and section 5 our methodology. The findings of our research are presented in section 6 , and finally, section 7 presents the conclusions, and future research directions.

\section{Returnable Transport Packaging}

Packaging prepares goods for safe, secure, efficient and effective handling, transport, distribution, storage, retailing, consumption and recovery, reuse or disposal combined with maximizing consumer value, sales and hence profit (Ballou, 2004; Saghir, 2004; Lambert et al,. 2011). At the same time packaging materials have contributed immensely to natural resource depletion, global warming, ozone layer depletion, and placing excessive pressure on the environment by the unceasing waste disposal (Kroon and Vrijens, 1995; 
Amienyo and Azapagic, 2016; Xie et al, 2016). In addition, packaging takes up landfill space, serves as sources of toxic materials with health implications and potential for groundwater contamination. To deal with the negative consequences of packaging, RTP enables firms to reduce their operational cost and lessening environmental impact in conformity with government regulations for sustainable supply chains (Silva et al., 2013; RPA, 2015). RTP signifies a change in attitude towards the environment for the purpose of environmental sustainability, but also for potentially achieving business performance. It is defined as packaging material for conveying large or small, heavy or light components from one phase of supply chain to another while improving the stability of products and reducing their damage (Wu and Dunn, 1995; Hellström and Johansson, 2010). Wu and Dunn (1995) illustrated how environmental and economic performance can be improved by adopting the usage of returnable packaging. Similarly, Kroon and Vrijens (1995) encouraged the usage of RTP so as to minimize environmental impact via waste reduction while reducing operational costs.

However, the usage of RTP may increase operational cost, including for example, transportation, sophisticated equipment, and tracing and tracking. These might pose as barriers to the adoption and use of RTP. Furthermore, barriers to the usage of RTP could be maintenance, storage and cost of administration (Kroon and Vrijens, 1995). Also, the management of RTP is resource-intensive. A survey conducted by the Aberdeen Group in 2004 suggested that the cost of managing logistics assets consumes $5 \%$ or more of the corporate revenue (Ilic et al, 2009). Shrinkage and attrition have created further challenges in managing logistics assets, and this is mostly caused by theft, customers' failure to return empty RTP, unreported damages of RTP, leading to emergency purchase of another set of RTP to cope with demand and supply requirements (Breen, 2006). Twede and Clarke (2004) also identified that RTP are misallocated and misplaced often as they are hardly tracked especially in transit. The need to provide additional fund for supplementary logistics assets and sufficient workforce to manage them poses additional challenges to organizations that would have to manage RTP both effectively and efficiently to avert potential negative consequences. To achieve this, strict measures in the implementation and management of RTP are needed, such as tracking and tracing (Shamsuzzoha and Helo, 2011) for highlevel visibility, and quality control of RTP movement using, for example, a controlled pool system (Maleki and Reimche, 2011). Tracking systems enhance product's identification and its actual location at any given time by connecting physical material flow with information systems (Stefansson and Tilanus, 2001; Johansson and Hellström , 2007). Furthermore, Tracking and tracing systems manage and control the conveyance of RTP, and reconcile RTP supply with demand (Johansson and Hellström, 2007). To manage 
tracking, Fritz and Schiefer (2009) posit that the necessary capabilities need to be in place to facilitate the initial source (backward tracing) and final destination (forward tracing) of a product at any phase of the supply chain.

RTP can be used to achieve logical, marketing, and environmental objectives. For logical objectives, RTP enables distribution, protects product, preserves environment, leading thereby to substantial economic and environmental benefits. Furthermore, RTP provides information about product's condition and location even on transit, which in turn brings operational benefits. Regarding the achievement of marketing objectives, RTP expedites graphic design, satisfies legislative demands on environmental sustainability and offers competitive advantage. It also assists firms in meeting their market demands by satisfying the requirements of customers, and guarantees convenience for distribution, which is a major advantage over the single-use packaging. Finally, when it comes to environmental objectives, RTP facilitates recovery and recycling hence progressively reduces waste disposal emanating from single-use packaging (Hellström and Saghir, 2007). However, literature so far has not explored how RTP could improve business performance.

Although scholars have acknowledged the benefits accruing from the use of RTP for supply chain effectiveness and sustainability, there is a dearth of studies that focus on its competitiveness capabilities and barriers associated with the practice. Bernon et al. (2011) as well as others (Rogers and TibbenLembke, 1998; Guide and Van Wassenhove, 2009) suggest that despite the importance placed by the literature on RL, limited empirical research has been undertaken to address the underlying aspects of it. Furthermore, this previous research did not look at developing countries (Abdulrahman et al., 2014). However, it must be acknowledged that the effective usage of RTP in $\mathrm{RL}$ will remain unattainable without identifying its barriers to effective implementation and optimal usage. To address the aforementioned gaps this research draws on natural resource based view (NRBV), which is discussed next.

\section{Natural resource based view of the firm}

The Natural-Resource-Based View of the firm (NRBV) (Hart, 1995; Hart and Dowell, 2010) builds on the earlier theory of Resource-Based-View (RBV), which postulates how competition can be attained through intra-firm resources and capabilities (Barney, 1991). The RBV acknowledges and emphasizes political, economic, social, and technological environment to the virtual exclusion of the natural environment (Hart, 1995; Shrivastava, 1995). The RBV focuses on the accumulation and deployment of firm-specific resources that are difficult to imitate and substitute (Wernerfelt, 1995; 
Hallgren et al, 2010). Resources are a combination of assets developed over time (Day, 1994; Perunovic et al, 2012) to provide distinctive capabilities that are the firm's sources of sustainable competitive advantage (Barney, 1991).

The RBV theory does not consider the impacts of the firm's operations on the natural environment or the life-cycle environmental costs of its products and services. However, given the growing concern for the ecosystem, this omission has rendered the theory inadequate as a basis for explaining sources of competitive advantage and for it to remain relevant, it must address and embrace the challenges of environmental sustainability.

Hart (1995) proposed the NRBV and suggested that the challenges regarding natural and social environments determine a company's competitive advantage as stemming from its capabilities to facilitate environmentally responsible activities. NRBV has been used to stress the importance of management capabilities in terms of achieving environmental performance and subsequently sustainable competitive advantage (e.g. Klassen and Whybark, 1999; Vachon and Klassen, 2007). Klassen and Whybark (1999) investigated the impact of pollution prevention and control technologies and found that those firms that implemented pollution prevention technologies improved their performance in terms of cost, speed, quality, and flexibility. Vachon and Klassen (2007) looked at the application of NRBV to link environmental collaboration to supply chain, as they studied environmental collaborative activity through logistical and technological integration.

In this paper, we follow the study of Klassen and Whybark (1999) and use NRBV to conceptualise the role of RTP as an environmental technology and a resource that could potentially impact positively on profitability whilst curtailing negative interactions with society and promoting environmental stewardship. A conceptual model is proposed, which is discussed in the next section.

\section{Conceptual model of RTP and hypotheses}

A number of authors (Kroon and Vrijens, 1995; Wu and Dunn, 1995; Twede and Clarke, 2004; Breen, 2006; Hellström and Saghir, 2007; Ilic et al., 2009) have elucidated on the drivers of, and barriers to, the usage of RTP. The key issue with RTP is the operational costs required for the effective and efficient management of the logistics assets. Operational costs are cost of transportation, cost of sophisticated equipment, cost of tracing and tracking and some other inevitable expenses. The management of RTP is resourceintensive (Aberdeen Group, 2004) due to the high operational costs required for a sustainable environment (Ilic et al., 2009). Furthermore, there is need for 
RTP investment justification to the shareholders. As such, it is essential to measure the cost-effectiveness of the usage of RTP based on the company size, the level of investment and the return on investment duration of RTP. Similarly, the challenges of organizational inertia and resistance to change are vital, including, the lack of understanding of the potential benefits associated with the adoption of RTP. Therefore, in industrial sectors such as fast moving consumer goods (FMCG) and manufacturing companies, where the usage of RTP is highly paramount, it is important to understand the impact of RTP on business performance.

Figure 1 explains our conceptual research model consisting of seven dimensions: (i) adoption of RTP, (ii) company turnover, (iii) drivers of RTP, (iv) barriers to RTP, (v) investment in RTP, (vi) return on investment duration, (vii) business performance.

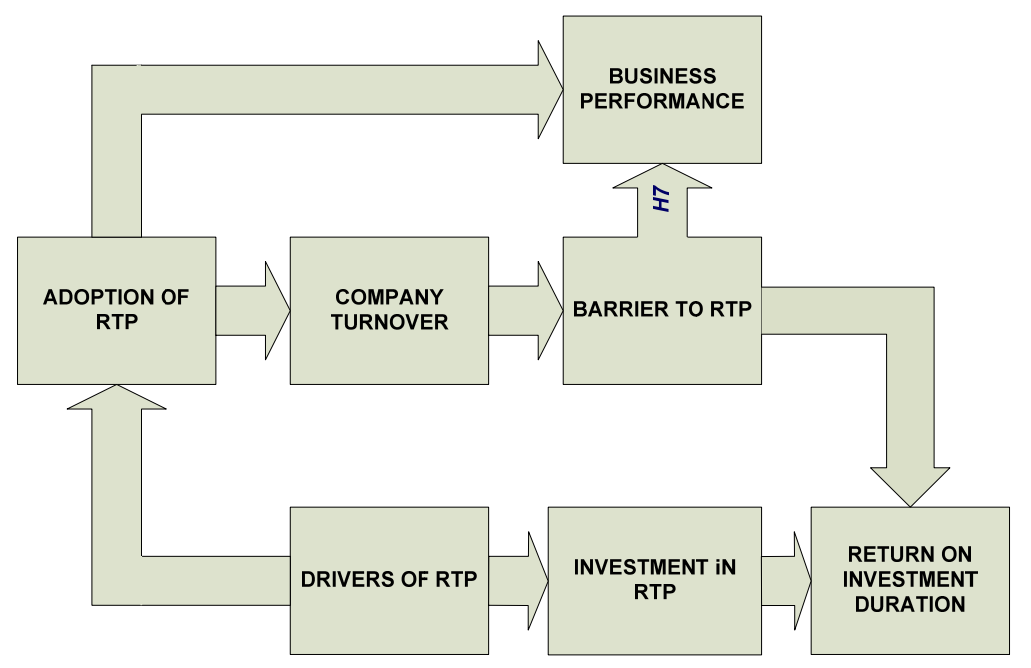

Figure 1: Conceptual Research model of RTP related factors

The conceptual model (Figure 1) illustrates the relationships among the seven dimensions with the arrows indicating the direction of influence. As indicated in the model, it is expected that the company's size as defined by annual turnover will influence the adoption of RTP in an organization. Conceptually, larger companies would be inclined to adopt the usage of RTP at a larger extent compared to smaller companies. The proposed drivers of RTP are government regulation, environmental consideration, economic benefits, operational benefits, social benefits, environmental benefits, competitive advantage, and advantages over single-use transport packaging. These are proposed to determine the adoption of RTP in RL and the level at which organizations invest in RTP in their businesses. The level of investment in RTP is projected to influence the return on investment duration. Similarly, business performance is measured based on the following performance measures (Klassen and Whybark, 1999): speed, quality of service/products, 
sales turnover, low cost, net profit, customer loyalty, competitive advantage, customer satisfaction, innovation, technology and internal rate of return.

Practically, the barriers to the usage of RTP should be relatively proportional to company size as defined by annual turnover. The barriers to the usage of RTP are loss of RTP, unavailability of sufficient storage space, costly sophisticated equipment, cost of tracing and tracking of RTP, high transportation cost of RTP, sorting and cleaning of used RTP, mix-ups during allocation and return of RTP, difficulties in managing or controlling RTP, and additional cost required for effective management of RTP. These barriers are anticipated to weaken the business performance and extend the duration of return on investment.

There are eight possible linkages between the major research constructs as shown in the Figure 1. But as this paper is focused on company turnover, RTP drivers, adoption and barriers and their impacts on business performance, a sub-model depicting the relationships between these five variables was extracted from Figure 1 and represented in Figure 2 below. Therefore, subsequent to earlier discussion, we hypothesise as follows:

H1: Size of the company as defined by annual turnover restrains the range of barriers to the use of RTP;

H2: The drivers of RTP influence its adoption;

H3: The adoption of RTP improves business performance;

H4: The barriers to the use of RTP weaken the business performance; 


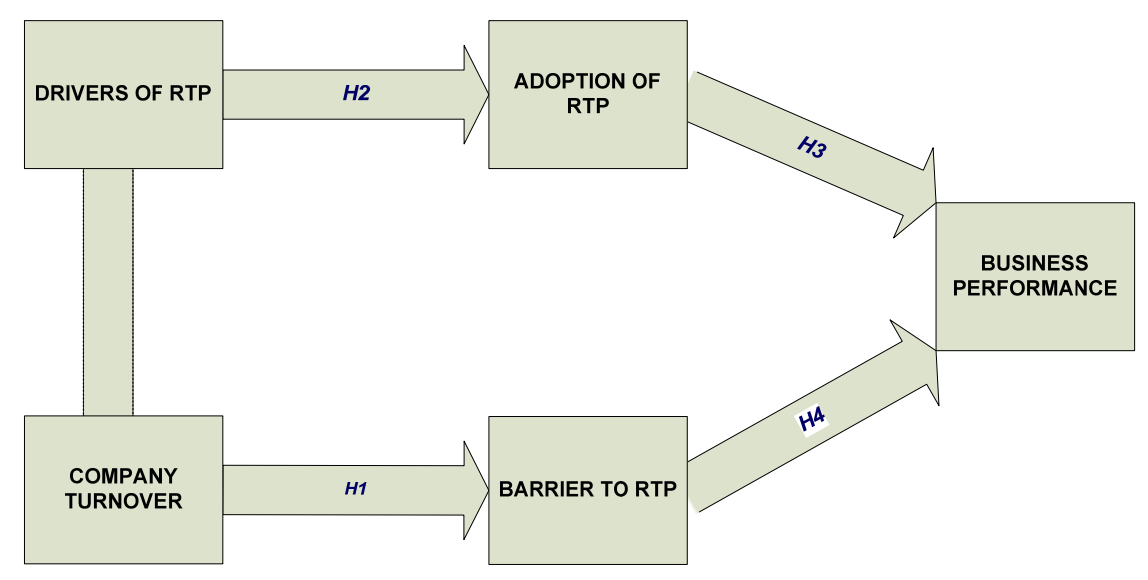

Figure 2: Sub-model of RTP related factors

\section{Research Methodology}

\subsection{Survey development}

A survey by questionnaire was conducted in the summer of 2014 to collect data from a random sample size of one hundred and twenty (120) companies from various business sectors in Nigeria and South Africa, resulting in 44 and 35 responses from both countries, respectively, and a total 79 responses altogether. We chose the survey methodology to test for theoretical relationships in large samples from businesses (Wacker, 1998). Survey appears to be the most-appropriate methodology for generating data from a large population (Wilson, 2014) and to test hypotheses. We used a nonexperimental survey for data collection, using the approach by Dillman (2000).

The survey (see Appendix) entailed three (3) sections of thirty-nine (39) questions that aimed at providing answers to the research questions. The first section (Part A) was designed to build the company profile of the participants. Open-ended questions regarding name, address, telephone number, email, and category questions regarding annual expenditure, the total number of employees of the company, among others, were included. The second section (Part B), by means of multiple-choice questions, investigated the single-use transport packaging and the factors debarring some organizations from switching to RTP. The third section (Part C) enquired the RTP under some subsections which included the commonly used RTP, cost effectiveness of RTP, potential benefits of RTP, managing and controlling RTP, possible 
challenges of RTP and the assessment of the usage of RTP. Questions in the third section entailed a combination of Likert-scale questions - to seek the best reflection of the respondents' opinion; closed-ended questions - to restrict the respondent to some specific and potential answers so as to make a comparative analysis of qualitative answers easy; multiple choice questions -where overlap in the choices was avoided; and open-ended questions - to give room for lengthy answers where applicable (Wilson, 2014). The questions in the second and third sections covered the major concerns of the RTP (Breen, 2006; Saghir, 2004; Wu and Dunn, 1995) as discussed earlier. They were relevant to those respondents whose company is yet to adopt the concept of RTP in their business. The questions in Part C were relevant to the respondents whose company has adopted the concept of RTP in their businesses. For instance, question 27 was formulated to buttress the point made by Kroon and Vrijens (1995) and Wu and Dunn (1995) on how environmental and economic performance can be improved by adopting RTP. The question equally investigated how other organizations' performance can be improved by adopting RTP.

\subsection{Data collection}

In line with Yun and Trumbo (2000), a multi-mode approach -a combination of internet and paper mail survey was implemented while administering the questionnaire- to generate responses from a greater range of individuals and boost the response rate. The multi-mode also known as mixed-mode approach equally creates a possibility of compensating for the flaws of each mode at affordable cost (De Leeuw, 2005). The paper mail questionnaire was initially sent out to potential participants, and a far less costly Internet survey was released for follow-up data collection. A covering letter was attached with the questionnaire to encourage the potential respondents in completing the questionnaire. Pre-notice and follow-up calls were used to enhance the response rate (Yun and Trumbo, 2000)

After six (6) weeks of administering the questionnaire, $7.5 \%$ response rate was generated via postage while $18.3 \%$ response rate was generated via electronic mails and $40 \%$ was generated via the web. Some responses were found unusable as the second and third sections of the questionnaire were left blank. Missing data (that were uncontrollable by the researcher) were assigned a missing code, which enabled the researcher to exclude them from the analysis and hence avoid any negative impact on the survey. 


\section{Results and analysis}

Data were analysed with descriptive and inferential statistical methods and SPSS. Normality, reliability, validity and non-response bias tests were conducted on the data to measure for result generalization on the usage of RTP in RL. Furthermore, Pearson chi-square test and Spearman's rank order correlation were used to test hypotheses. Other tests including crosstabulation, coefficient of determination, factor analysis, Kaiser-Meyer-Olkin and Bartlett's test were used to assess the relationships of the research variables. However, some of the results of the analysis are not included in this paper in order not to exceed the stipulated length.

\subsection{Profile of the respondents}

Table 1 depicts the profile of the respondent firms. The respondents' profiles were described by supply channel position, size of organizations evaluated by number of employees and size of organizations evaluated by the annual turnover. With regard to the supply channel position, $30.4 \%$ of the respondents operate as retailers while $43 \%$ operate as wholesalers. The highest response rate under the category of supply channel position (i.e. $60.8 \%$ ) was the manufacturers. This indicates that the sample population is well-distributed across the three supply channel positions. Furthermore, the respondents were classified with respect to each company's number of employees (Table 1). Following the classification made by the European Union, a small and medium enterprise (SME) is made up of enterprises with a labour force less than 250 and an annual turnover not more than $£ 40 \mathrm{M}$ (Europa, nd). This indicates that in terms of number of employees, a total of $66.3 \%$ of the respondents are SMEs, while $33.8 \%$ are large enterprises. Also, from the perspective of annual turnover, $68.9 \%$ of the respondents are SMEs while $31.1 \%$ are large enterprises. 
Table 1: Profile of the respondents

\begin{tabular}{|c|c|c|c|}
\hline \multicolumn{3}{|c|}{ Criteria } & Percentages \\
\hline \multicolumn{4}{|c|}{ Supply channel position } \\
\hline \multirow[t]{3}{*}{ Manufacturer } & \multicolumn{2}{|l|}{ Yes } & 60.8 \\
\hline & \multicolumn{2}{|l|}{ No } & 39.2 \\
\hline & \multicolumn{2}{|l|}{ Total } & 100.0 \\
\hline \multirow[t]{3}{*}{ Wholesalers } & \multicolumn{2}{|l|}{ Yes } & 43.0 \\
\hline & \multicolumn{2}{|l|}{ No } & 57.0 \\
\hline & \multicolumn{2}{|l|}{ Total } & 100 \\
\hline \multirow[t]{3}{*}{ Retailers } & \multicolumn{2}{|l|}{ Yes } & 30.4 \\
\hline & \multicolumn{2}{|l|}{ No } & 69.6 \\
\hline & \multicolumn{2}{|l|}{ Total } & 100.0 \\
\hline \multicolumn{3}{|c|}{ Number of employees } & \\
\hline \multicolumn{3}{|c|}{$1-10$} & 2.6 \\
\hline \multicolumn{3}{|l|}{$11-50$} & 27.3 \\
\hline \multicolumn{3}{|l|}{$51-250$} & 36.4 \\
\hline \multicolumn{3}{|l|}{$251-500$} & 10.4 \\
\hline \multicolumn{3}{|l|}{501 and above } & 23.4 \\
\hline \multicolumn{3}{|l|}{ Total } & 100.0 \\
\hline \multicolumn{3}{|c|}{ Annual turnover } & \\
\hline \multicolumn{3}{|l|}{$<f 5 M$} & 29.9 \\
\hline \multicolumn{3}{|l|}{$f 5 M-f 20 M$} & 31.2 \\
\hline \multicolumn{3}{|l|}{$f 21 M-f 50 M$} & 7.8 \\
\hline \multicolumn{3}{|l|}{$f 51 M-f 100 M$} & 10.4 \\
\hline \multicolumn{3}{|l|}{$>£ 100 M$} & 20.8 \\
\hline \multicolumn{3}{|l|}{ Total } & 100.0 \\
\hline \multicolumn{4}{|c|}{ Country breakdown of samples and respondents } \\
\hline Country & $\begin{array}{c}\mathrm{N} \\
\text { (Sample) }\end{array}$ & $\begin{array}{c}\mathrm{N} \\
\text { (Respondents) }\end{array}$ & \\
\hline Nigeria & 70 & 42 & 54.55 \\
\hline South Africa & 50 & 35 & 45.45 \\
\hline Total & 120 & 77 & 100 \\
\hline
\end{tabular}


6.2: Normality, reliability, and validity tests

To test for normality, skewness and kurtosis tests were used (Thode, 2002). All the essential variables for this study were assessed for normality, and they all fell within the required range (value less than 3) of normality as in skewness and kurtosis test (Tabachnick and Fidell, 2001) (Table 2).

Table 2: Skewness and Kurtosis test of normality for research variables

\begin{tabular}{|l|c|c|c|c|c|c|}
\hline Variables & Min & Max & Mean & STD. Dev. & Skewness & Kurtosis \\
\hline Loss of RTP & 1 & 5 & 3.38 & 1.001 & -0.037 & -0.621 \\
\hline Sorting and cleaning of RTP & 1 & 5 & 3.43 & 1.059 & -0.186 & -0.493 \\
\hline Quality of service/products & 1 & 5 & 4.39 & 0.846 & -1.987 & 2.875 \\
\hline Sales turnover & 2 & 5 & 4.23 & 0.786 & -0.907 & 0.63 \\
\hline Cost saving & 2 & 5 & 4.57 & 0.657 & -1.672 & 0.754 \\
\hline Storage efficiency & 1 & 5 & 4.39 & 0.867 & -1.739 & 1.603 \\
\hline
\end{tabular}

Cronbach's Alpha was used to perform the reliability test (Flynn et al., 1990; Forza, 2002) with Table 3 showing alpha values for the major constructs in this study. From the Table 3, it can be deduced that the coefficient alpha for all the main elements are so close to 1 , which implies a strong internal consistency of the variables, and the survey instrument is thus reliable (Forza, 2002).

Table 3: Reliability test output

\begin{tabular}{lc}
\hline Constructs & $\begin{array}{l}\text { Cronbach's } \\
\text { alpha }\end{array}$ \\
\hline Business performance measures & 0.857 \\
Barriers to the usage of returnable transport & \\
packaging & 0.866 \\
Drivers of returnable transport packaging & 0.884 \\
\hline
\end{tabular}

SPSS ANOVA independent t-test was used to test the external validity for potential non-response bias based on the $65.8 \%$ response obtained. The variability in the first and second half of the responses is not significantly different as the values for Levene's t-test, and the two-tailed significance are greater than 0.05 (Table 4). 
Table 4: ANOVA test of non-response bias.

\begin{tabular}{|c|c|c|c|c|c|}
\hline Variable & $\begin{array}{c}1^{\text {st }} \\
\text { Wave }\end{array}$ & $\begin{array}{c}2^{\text {nd }} \\
\text { Wave }\end{array}$ & df & $\begin{array}{l}\text { Sig. (2- } \\
\text { tailed) }\end{array}$ & $\begin{array}{c}\text { Levene's } \\
\text { test }\end{array}$ \\
\hline \multirow{2}{*}{ Speed } & \multirow{2}{*}{3.69} & \multirow{2}{*}{3.74} & 53 & 0.125 & \multirow{2}{*}{0.113} \\
\hline & & & 31.643 & 0.164 & \\
\hline \multirow{2}{*}{ Low cost } & \multirow{2}{*}{3.55} & \multirow{2}{*}{3.82} & 52 & 0.952 & \multirow{2}{*}{0.057} \\
\hline & & & 33.575 & 0.956 & \\
\hline \multirow{2}{*}{ Sales turnover } & \multirow{2}{*}{3.04} & \multirow{2}{*}{3.28} & 54 & 0.822 & \multirow{2}{*}{0.863} \\
\hline & & & 46.36 & 0.823 & \\
\hline \multirow{2}{*}{ Net profit } & \multirow{2}{*}{2.73} & \multirow{2}{*}{2.97} & 54 & 0.853 & \multirow{2}{*}{0.993} \\
\hline & & & 49.792 & 0.851 & \\
\hline \multirow{2}{*}{ Market share } & \multirow{2}{*}{3.82} & \multirow{2}{*}{3.71} & 54 & 0.667 & \multirow{2}{*}{0.729} \\
\hline & & & 49.359 & 0.663 & \\
\hline \multirow{2}{*}{$\begin{array}{c}\text { Customer } \\
\text { loyalty }\end{array}$} & \multirow{2}{*}{3.82} & \multirow{2}{*}{3.64} & 54 & 0.007 & \multirow{2}{*}{0.152} \\
\hline & & & 53.912 & 0.005 & \\
\hline \multirow{2}{*}{$\begin{array}{l}\text { Competitive } \\
\text { advantage }\end{array}$} & \multirow{2}{*}{3.55} & \multirow{2}{*}{3.59} & 54 & 0.15 & \multirow{2}{*}{0.685} \\
\hline & & & 46.291 & 0.154 & \\
\hline \multirow{2}{*}{$\begin{array}{c}\text { Customer } \\
\text { satisfaction }\end{array}$} & \multirow{2}{*}{3.2} & \multirow{2}{*}{3.38} & 53 & 0.139 & \multirow{2}{*}{0.208} \\
\hline & & & 52.361 & 0.104 & \\
\hline \multirow{2}{*}{$\begin{array}{c}\text { Quality of } \\
\text { service/products }\end{array}$} & \multirow{2}{*}{3.17} & 32 & 54 & 0.334 & 0430 \\
\hline & & 0.0 & 36.862 & 0.365 & 0.459 \\
\hline Innoration & 347 & 382 & 54 & 0.017 & 0815 \\
\hline Mimovaciois & 0.41 & 0.02 & 51.149 & 0.015 & 0.010 \\
\hline Technolnoy & $3 \Omega ?$ & 3.14 & 54 & 0.246 & 0059 \\
\hline f Comorozy & 0.02 & U.1T & 52.501 & 0.229 & 0.009 \\
\hline Internal rate of & 245 & 286 & 54 & 0.826 & 0102 \\
\hline return & 2.45 & 2.00 & 48.901 & 0.824 & 0.192 \\
\hline
\end{tabular}

\subsection{General Observations}

Analysing the data, it was observed that $70.9 \%$ of the respondents have adopted the usage of RTP considering the potential benefits it holds, while $29.1 \%$ are yet to adopt (Table 5). This is an indication that the majority of the companies sampled in Nigeria and South Africa have switched from the conventional single-use transport packaging to the usage of RTP.

However, as indicated in Table 5, a very low response rate (4.3\%) of those that are yet to adopt the usage of RTP in their businesses appear certain of implementing RTP in the future. Some $73.9 \%$ are not sure of considering its implementation while $21.7 \%$ are not considering RTP. This result might be 
connected to lack of funds or of knowledge regarding the potential benefits of RTP.

Table 5: Observed adoption level of RTP

\begin{tabular}{lc}
\hline Constructs & Percentage \\
\hline Adoption of RTP & \\
\hline Yes & 70.9 \\
No & 29.1 \\
Total & 100.0 \\
\hline Future consideration for the adoption & \\
of RTP & \\
\hline Absolutely yes & 4.3 \\
May be & 52.2 \\
May be not & 21.7 \\
Absolutely no & 21.7 \\
Total & 100.0 \\
\hline
\end{tabular}

Furthermore, as elucidated by Breen (2006), shrinkage and attrition were detected as significant problems encountered by organizations in using RTP, which could be considered as barriers to the usage of RTP. The analysis also reflects other barriers that could be linked to the rationale behind the nonadoption of RTP by some organizations in Nigeria and South Africa (Table 6).

Table 6: The potential barriers to the adoption of RTP in Nigeria and South Africa companies

\begin{tabular}{|c|c|c|c|c|c|c|}
\hline Barriers to adoption of RTP & Strongly disagree (\%) & Disagree (\%) & Neutral (\%) & Agree (\%) & Strongly agree (\%) & Total (\%) \\
\hline High transportation cost of RTP & 3.6 & 8.9 & 39.3 & 28.6 & 19.6 & 100.0 \\
\hline Loss of RTP in transit & 1.8 & 17.9 & 35.7 & 30.4 & 14.3 & 100.0 \\
\hline Unavailability of sufficient storage space & 3.6 & 10.7 & 21.4 & 30.4 & 33.9 & 100.0 \\
\hline Costly sophisticated equipment & 1.8 & 17.9 & 41.1 & 25.0 & 14.3 & 100.0 \\
\hline Delay of other deliveries & 3.6 & 14.3 & 51.8 & 17.9 & 12.5 & 100.0 \\
\hline Delay in RTP pick-up by suppliers & 3.6 & 8.9 & 42.9 & 33.9 & 10.7 & 100.0 \\
\hline Sorting an cleaning of used RTP & 3.6 & 14.3 & 35.7 & 28.6 & 17.9 & 100.0 \\
\hline Mix-ups during RTP allocation and return & 3.6 & 16.1 & 44.6 & 19.6 & 16.1 & 100.0 \\
\hline Cost of tracing and tracking of RTP & 3.6 & 16.1 & 37.5 & 23.2 & 19.6 & 100.0 \\
\hline Difficulties in managing and controlling RTP & 5.4 & 17.9 & 37.5 & 16.1 & 23.2 & 100.0 \\
\hline Additional cost required for managing and controlling RTP & 1.8 & 12.5 & 28.6 & 41.1 & 16.1 & 100.0 \\
\hline
\end{tabular}




\subsection{Test of Hypotheses}

\subsubsection{Test of Hypothesis One (H1)}

The alternate hypothesis $\left(\mathrm{H}_{1}\right)$ and null hypotheses $\left(\mathrm{H}_{\circ}\right)$ state:

$\mathrm{H}_{1}$ : The size of the company as defined by annual turnover restrains the range of barriers to the use of RTP in reverse logistics.

$\mathrm{H}_{\mathrm{o}}$ : The size of the company as defined by annual turnover does not restrain the range of barriers to the use of RTP in reverse logistics.

Spearman's rank order correlation (Pallant, 2010) was used to measure the relationship between the two categorical variables, that is, annual turnover and barriers to the use of RTP. Our results (see Table 7) show that the significant level of the concerned variables (annual turnover and barriers) are all greater than 0.05 ( $\mathrm{p}$-value), hence the null hypothesis is adopted. It is therefore proven statistically that the size of the company as defined by annual turnover does not moderate the range of barriers to the use of RTP in reverse logistics. The effect of the relationship between the annual turnover and barriers to the use of RTP was also examined by Spearman's correlation (Table 7). High transportation cost of RTP, unavailability of sufficient storage space, and difficulties in managing/controlling of RTP recorded -0.066, -0.026 and -0.061 respectively. This depicts an inverse slight relationship with annual turnover. This could be regarded as a relationship so low as to be random. Loss of RTP in transit recorded as 0 , which means it has no relationship with annual turnover and could be concluded that the observed results were produced based on chance. However, some of the enlisted barriers indicate an iota of association with annual turnover, measured statistically. Cost of tracing and tracking of RTP, costly sophisticated equipment, delay of order deliveries, delay in RTP pick-up, sorting and cleaning of used RTP, mix-ups during RTP allocation and return, and additional cost required for managing/controlling RTP recorded 0.064, 0.122, $0.103,0.161,0.273,0.236$ and 0.22 respectively, describe very weak relationships with annual turnover.

Furthermore, the coefficient of determination is calculated to determine the proportion of variance that exists between the two variables. Using the formula, coefficient of determination $=\operatorname{rho}^{2}(\mathrm{x} 100) \%$ variance, where the correlation coefficient is denoted by rho in Spearman's rank order coefficient, the respective proportion of variance is illustrated in Table 7.

According to Burns and Burns (2008), there are four (4) different relationships that could exist in variables as follows:

- No common variance as a result of no correlation. 
- $9 \%$ common variance as a result of a small correlation of +0.3 .

- $49 \%$ common variance as a result of a high correlation of +0.7 .

- $90 \%$ common variance as a result of an extremely high correlation of +0.95 .

The proportion of variance that exists between annual turnover and the barriers to RTP as indicated in Table 7 can be classified as "no common variance" as a result of no correlation.

Table 7: Correlations of Annual turnover and barriers to RTP adoption

\begin{tabular}{|l|c|c|c|c|}
\hline \multicolumn{5}{|c|}{ Correlations } \\
\hline \multicolumn{5}{|c|}{ Annual Turnover and Barriers to RTP } \\
\hline & $\begin{array}{l}\text { Correlation } \\
\text { Coefficient }\end{array}$ & Sig. (1-tailed) & Nariance \% \\
\hline Annual Turnover & 1.000 &. & 77 & \\
\hline High Transportation Cost of RTP & -0.066 & 0.318 & 54 & 0.436 \\
\hline Loss of RTP in Transit & 0.000 & 0.500 & 54 & 0.000 \\
\hline Unavailability of Sufficient Storage Space & -0.026 & 0.427 & 54 & 0.068 \\
\hline Costly Sophisticated Equipment & 0.122 & 0.189 & 54 & 1.488 \\
\hline Delay of Other Deliveries & 0.103 & 0.229 & 54 & 1.061 \\
\hline Delay in RTP Pick-up & 0.161 & 0.123 & 54 & 2.592 \\
\hline Sorting and Cleaning of Used RTP & 0.273 & 0.023 & 54 & 7.453 \\
\hline Mix-ups during RTP Allocation and Return & 0.236 & 0.043 & 54 & 5.570 \\
\hline Cost of Tracing and Tracking of RTP & 0.064 & 0.322 & 54 & 0.410 \\
\hline Difficulties in Managing / Controlling of RTP & -0.061 & 0.330 & 54 & 0.372 \\
\hline Additional Cost Required for Managing / Controlling RTP & 0.220 & 0.055 & 54 & 4.840 \\
\hline
\end{tabular}

\subsubsection{Test of Hypothesis Two (H2)}

The alternate hypothesis $\left(\mathrm{H}_{2}\right)$ and null hypothesis $\left(\mathrm{H}_{\mathrm{o}}\right)$ sate:

$\mathrm{H}_{2}$ : The drivers of RTP influence the adoption of RTP.

$\mathrm{H}_{\mathrm{o}}$ : The drivers of RTP do not influence the adoption of RTP.

As shown in Table 8, the significant level of the adoption of RTP and the drivers of RTP are less than the alpha level of 0.05. Therefore the null hypothesis is rejected and the alternate hypothesis is accepted. This implies that there is a statistically significant relationship between the drivers of RTP and the adoption of RTP. 
Drivers such as government regulations, competitive advantage and advantages over single-use recorded a correlation coefficient of $0.262,0.2$ and 0.249 respectively, implying low correlations with the adoption of RTP. The relationship effect size of these drivers and adoption of RTP can be considered low according to Cohen's (1992) convention. Other drivers (environmental consideration, economic benefits, environmental benefits, operational benefits and social benefits) reported $0.47,0.358,0.439,0.462$ and 0.33 respectively implying a moderate correlation. The relationship strength of the later set of drivers with the adoption of RTP is certainly higher than the former ones. This means that most organizations are more interested in the environmental, economic, social and operational benefits when adopting RTP. Government regulations, competitive advantage and advantages over singleuse did not seem to be as important as the other drivers discussed. Here we assume a more liberal definition of competitive advantage as the perception of adoptees of RTP to view it as granting a business advantage over rivals.

The coefficient of determination was calculated to delineate the proportion of variance that exists between adoption of RTP and drivers of RTP. This is presented in Table 8, indicating that the percentage of variance in adoption of RTP is predictable from the variance in five of the drivers of RTP. For environmental consideration, economic benefits, environmental benefits, operational benefits and social benefits over $9 \%$ variance was recorded, which implies a common variance. The other drivers (government regulations, competitive advantage and advantages over single-use) have no common variance with the adoption of RTP.

Table 8: Pearson Chi-square correlation for drivers of RTP and adoption of RTP

\begin{tabular}{|l|c|c|c|c|}
\hline \multicolumn{5}{|c|}{ Correlations } \\
\hline \multicolumn{5}{|c|}{ Drivers of RTP and Adoption of RTP } \\
\hline & $\begin{array}{c}\text { Correlation } \\
\text { Coefficient }\end{array}$ & Sig. (1-tailed) & N & \%Variance \\
\hline Adoption of RTP & 1.000 &. & 56 & \\
\hline Government Regulation & 0.262 & 0.004 & 56 & 6.864 \\
\hline Environmental Consideration & 0.470 & 0.004 & 56 & 22.090 \\
\hline Economic Benefits & 0.358 & 0.002 & 56 & 12.816 \\
\hline Environmental Benefits & 0.439 & 0.005 & 56 & 19.272 \\
\hline Operational Benefits & 0.462 & 0.006 & 54 & 21.344 \\
\hline Social Benefits & 0.330 & 0.001 & 55 & 10.890 \\
\hline Competitive Advantage & 0.200 & 0.001 & 55 & 4.000 \\
\hline Advantages over Single-use & 0.249 & 0.007 & 55 & 6.200 \\
\hline
\end{tabular}




\subsection{3: Test of Hypothesis three (H3)}

The alternate hypothesis $\left(\mathrm{H}_{3}\right)$ and null hypothesis $\left(\mathrm{H}_{\circ}\right)$ state:

$\mathrm{H}_{3}$ : Adoption of RTP improves business performance.

$\mathrm{H}_{\mathrm{o}}$ : Adoption of RTP does not improve business performance.

Descriptive statistics were used to summarize the respondents' opinions on the impact of RTP adoption on business performance using various performance measures (Table 9). Hence, it can be inferred that the usage of RTP has a high level of positive impact on business performance based on the general performance measures. For instance, $92.9 \%$ of the respondents indicated that the usage of RTP has a high level of positive impact on the quality of service and (or) products. This shows that the conveyance of their products by RTP from one phase of the supply chain to the other has significantly increased the quality offerings of their products and services. Also, $87 \%$ of the respondents indicated that the usage of RTP has a high positive impact on their company's performance defined by low cost. This can be justified by the rate at which revenue is generated from usage of RTP when the companies start recuperating their capital investments in adoption once the break-even point of three years is reached.

Table 9: Impact of RTP adoption on business performance

\begin{tabular}{|l|c|c|c|c|c|}
\hline & \multicolumn{5}{|c|}{ Impact of RTPs on Company's Performance Measures (in \%) } \\
\hline Performance Measures & $\begin{array}{c}\text { Very Negative } \\
\text { Impact }\end{array}$ & $\begin{array}{c}\text { Some Negative } \\
\text { Impact }\end{array}$ & No Impact & $\begin{array}{c}\text { Some Positive } \\
\text { Impact }\end{array}$ & $\begin{array}{c}\text { Very Positive } \\
\text { Impact }\end{array}$ \\
\hline Quality of service/products & 1.8 & 3.5 & 1.8 & 39.3 & 53.6 \\
\hline Speed & 1.8 & 1.8 & 9.1 & 63.6 & 23.7 \\
\hline Low cost & 0 & 1.9 & 11.1 & 59.3 & 27.7 \\
\hline Sales turnover & 0 & 3.6 & 10.7 & 44.6 & 41.1 \\
\hline Net profit & 0 & 1.8 & 10.7 & 53.6 & 33.9 \\
\hline Market share & 0 & 3.6 & 39.3 & 44.6 & 12.5 \\
\hline Customer loyalty & 0 & 3.6 & 16.1 & 64.3 & 16.2 \\
\hline Competitive advantage & 0 & 3.6 & 17.9 & 50 & 28.7 \\
\hline Customer satisfaction & 0 & 1.8 & 12.7 & 54.6 & 30.9 \\
\hline Innovation & 0 & 1.8 & 17.8 & 51.8 & 28.6 \\
\hline Technology & 0 & 1.7 & 30.4 & 55.4 & 12.5 \\
\hline Internal rate of return & 1.7 & 3.6 & 12.5 & 64.3 & 17.9 \\
\hline
\end{tabular}

Therefore, based on the above dataset and analysis, it can be concluded that adoption of RTP improves business performance.

The null hypothesis was further tested using the Pearson Chi-square test. The results presented in Table 10 show that the significant level for the adoption of RTP and the business performance are less than the alpha level of 0.05. As such, it is sufficient to reject the null hypothesis in favour of the 
alternate hypothesis, which infers that there is a statistically significant relationship between the two variables, meaning that the adoption of RTP improves business performance.

Table 10: Pearson Chi-square correlation for adoption of RTP and business performance

\begin{tabular}{|l|c|c|c|c|}
\hline \multicolumn{5}{|c|}{ Pearson Chi-Square Tests } \\
\hline \multicolumn{4}{|c|}{ Adoption of RTP and Business Performance } \\
\hline & $\begin{array}{c}\text { Correlation } \\
\text { Coefficient }\end{array}$ & Sig. (1-tailed) & N & \% Variance \\
\hline Adoption of RTP & 1 &. & 56 & \\
\hline Quality of Service /Products & 0.607 & 0.007 & 56 & 36.845 \\
\hline Speed & 0.528 & 0.004 & 56 & 27.878 \\
\hline Low Cost & 0.448 & 0.001 & 56 & 20.070 \\
\hline Sales Turnover & 0.447 & 0.001 & 56 & 19.981 \\
\hline Net Profit & 0.333 & 0.002 & 56 & 11.089 \\
\hline Market Share & 0.234 & 0.008 & 56 & 5.476 \\
\hline Customer Loyalty & 0.359 & 0.007 & 56 & 12.888 \\
\hline Competitive Advantage & 0.463 & 0.001 & 56 & 21.437 \\
\hline Customer Satisfaction & 0.354 & 0.009 & 56 & 12.532 \\
\hline Innovation & 0.299 & 0.006 & 56 & 8.940 \\
\hline Technology & 0.252 & 0.006 & 56 & 6.350 \\
\hline Internal Rate of Return & 0.354 & 0.005 & 56 & 12.532 \\
\hline
\end{tabular}

The correlation coefficient (Table 10) can be categorized into two categories (Cohen, 1992). Adoption of RTP and each of the performance measures under category 1 (which comprises of net profit, market share, customer loyalty, customer satisfaction, innovation, technology and internal rate of return) recorded correlation coefficient near 0.2. This indicates a small effect size relationship. Conversely, the adoption of RTP and each of the performance measures under category 2 (which comprises of quality of service/products, speed, low cost, sales turnover and competitive advantage) reported correlation coefficient close to 0.5. This indicates a medium effect size relationship. Largely, it can be established that the adoption of RTP improves business performance measures, though at varying rates.

Furthermore, the coefficient of determination was calculated to determine the proportion of variance that exists between the two variables (Table 10). The percentage of variance in the business performance measures is predictable from the variance in the adoption of RTP, as there exists common variance at various degrees. 
The alternate hypothesis $\left(\mathrm{H}_{4}\right)$ and the null hypothesis $\left(\mathrm{H}_{0}\right)$ state:

$\mathrm{H}_{4}$ : The barriers to the use of RTP weaken the business performance.

$\mathrm{H}_{0}$ : The barriers to the use of RTP do not weaken the business performance.

The null hypothesis was tested by spearman's rank order correlation (Table 11). The Table 11 suggests that the significant level for most of the barriers and business performance measures are less than the p-value of 0.05 , which indicates that the null hypothesis should be rejected in favour of the alternate hypothesis and hence the barriers to RTP deteriorate business performance. However, it is expedient to measure the strength of the relationship that exists between the different barriers and the various business performance measures. The relationship strength differs based on their correlation coefficients and can be categorized into small and moderate effect size (Cohen, 1992) represented in Table 12 and Table 13 respectively.

Table 11: Spearman's rank order correlation for barriers to RTP and business performance

\begin{tabular}{|c|c|c|c|c|c|c|c|c|c|c|c|c|c|c|}
\hline \multicolumn{3}{|c|}{ Correlation } & \multirow{2}{*}{$\begin{array}{c}\begin{array}{c}\text { Quality of } \\
\text { Service I } \\
\text { Products }\end{array} \\
.179\end{array}$} & \multirow{2}{*}{$\begin{array}{c}\text { Speed } \\
.118 \\
\end{array}$} & \multirow{2}{*}{$\begin{array}{c}\text { Low Cost } \\
.140\end{array}$} & \multirow{2}{*}{$\begin{array}{c}\begin{array}{c}\text { Sales } \\
\text { Turnover }\end{array} \\
-.084 \\
\end{array}$} & \multirow{2}{*}{\begin{tabular}{c|} 
Net profit \\
.032 \\
\end{tabular}} & \multirow{2}{*}{\begin{tabular}{|c|}
$\begin{array}{c}\text { Market } \\
\text { Share }\end{array}$ \\
$.225^{\star}$ \\
\end{tabular}} & \multirow{2}{*}{\begin{tabular}{|c|}
$\begin{array}{c}\text { Customer } \\
\text { Loyalty }\end{array}$ \\
.195 \\
\end{tabular}} & \multirow{2}{*}{$\begin{array}{c}\begin{array}{c}\text { Competitive } \\
\text { advantage }\end{array} \\
-.035 \\
\end{array}$} & \multirow{2}{*}{$\begin{array}{c}\begin{array}{c}\text { Customer } \\
\text { satisfaction }\end{array} \\
.025 \\
\end{array}$} & \multirow{2}{*}{\begin{tabular}{|c|} 
Innovation \\
.219 \\
\end{tabular}} & \multirow{2}{*}{\begin{tabular}{|c|} 
Technology \\
$.244^{\star}$ \\
\end{tabular}} & \multirow{2}{*}{$\begin{array}{c}\text { Internal } \\
\text { Rate of } \\
\text { Return } \\
-.094 \\
\end{array}$} \\
\hline & & Correlation Coefficient & & & & & & & & & & & & \\
\hline & Transportation & \begin{tabular}{|l} 
Sig. (1-tailed) \\
\end{tabular} & .094 & .195 & .156 & .269 & 407 & .048 & .075 & 399 & 428 & .052 & .035 & .246 \\
\hline & & $\mathrm{N}$ & 56 & 55 & 54 & 56 & 56 & 56 & 56 & 56 & 55 & 56 & 56 & 56 \\
\hline & & Correlation Coefficient & .188 & .148 & .156 & $.422^{\prime \prime}$ & $.422^{*+}$ & .099 & $.285^{\circ}$ & .211 & .204 & .147 & -.003 & $285^{\circ}$ \\
\hline & Transit & Sig. (1-tailed) & .083 & .141 & .130 & .001 & .001 & .234 & .017 & .059 & .068 & .140 & .490 & .017 \\
\hline & & $\mathrm{N}$ & 56 & 55 & 54 & 56 & 56 & 56 & 56 & 56 & 55 & 56 & 56 & 56 \\
\hline & Unavailability of & Correlation Coefficient & .194 & .054 & -.087 & .214 & .059 & $-.254^{*}$ & -.057 & .218 & .175 & $.290^{*}$ & .007 & .162 \\
\hline & Sufficient Storage & Sig. (1-tailed) & .075 & 348 & .265 & .057 & .333 & .029 & .339 & .054 & .101 & .015 & 480 & .116 \\
\hline & & $\mathrm{N}$ & 56 & 55 & 54 & 56 & 56 & 56 & 56 & 56 & 55 & 56 & 56 & 56 \\
\hline & & Correlation Coefficient & $328^{* \prime}$ & $.237^{*}$ & -.140 & $315^{\prime \prime}$ & $.271^{\star}$ & $-.248^{*}$ & .086 & .205 & .085 & 190 & .131 & .156 \\
\hline & Sophisticated & Sig. (1-tailed) & .007 & .041 & .157 & .009 & .022 & .033 & .265 & .065 & .270 & .080 & .169 & .126 \\
\hline & Equipment & $\mathrm{N}$ & 56 & 55 & 54 & 56 & 56 & 56 & 56 & 56 & 55 & 56 & 56 & 56 \\
\hline & & \begin{tabular}{|l|} 
Correlation Coefficient \\
\end{tabular} & -.045 & .027 & .070 & .028 & -.007 & -.212 & .053 & .159 & .022 & .005 & -105 & -.168 \\
\hline & Deliveries & Sig. (1-tailed) & .372 & .422 & .308 & 418 & .480 & .058 & .350 & .121 & .435 & 486 & .220 & .107 \\
\hline & & $\mathrm{N}$ & 56 & 55 & 54 & 56 & 56 & 56 & 56 & 56 & 55 & 56 & 56 & 56 \\
\hline \multirow{18}{*}{$\begin{array}{l}\text { Spearman's } \\
\text { rho }\end{array}$} & & Correlation Coefficient & .049 & .048 & .172 & .202 & .215 & .056 & .074 & .008 & -.038 & .210 & .125 & .034 \\
\hline & Up & Sig. (1-tailed) & .360 & 363 & .107 & .067 & .056 & .342 & .294 & 476 & .391 & .061 & .179 & .402 \\
\hline & & $\mathrm{N}$ & 56 & 55 & 54 & 56 & 56 & 56 & 56 & 56 & 55 & 56 & 56 & 56 \\
\hline & Sorting and & \begin{tabular}{|l|} 
Correlation Coefficient \\
\end{tabular} & .052 & $.225^{\circ}$ & $.302^{*}$ & $.287^{\circ}$ & $.256^{*}$ & .041 & .119 & 0.179 & 0.188 & 0.224 & $.224^{*}$ & $.230^{\circ}$ \\
\hline & Cleaning of Used & Sig. (1-tailed) & .351 & .049 & .013 & .016 & .028 & .382 & .191 & .088 & .169 & .057 & .048 & .044 \\
\hline & & $\mathrm{N}$ & 56 & 55 & 54 & 56 & 56 & 56 & 56 & 56 & 55 & 56 & 56 & 56 \\
\hline & Mix-ups during & Correlation Coefficient & .053 & .184 & $.271^{*}$ & $.324^{* \prime}$ & $.234^{*}$ & .097 & .096 & .163 & $.232^{*}$ & $.282^{*}$ & $.411^{* 1}$ & $.245^{\circ}$ \\
\hline & RTP Allocation & Sig. (1-tailed) & .350 & .090 & .024 & .007 & .042 & .239 & .241 & .115 & .044 & .052 & .001 & .034 \\
\hline & and Return & $\mathrm{N}$ & 56 & 55 & 54 & 56 & 56 & 56 & 56 & 56 & 55 & 56 & 56 & 56 \\
\hline & Cost of Tracing & \begin{tabular}{|l|} 
Correlation Coefficient \\
\end{tabular} & .038 & .133 & .038 & $348^{\prime \prime}$ & $.268^{*}$ & $-.262^{*}$ & $\begin{array}{l}-.126 \\
\end{array}$ & .090 & .016 & .126 & .068 & $277^{\circ}$ \\
\hline & and Tracking of & \begin{tabular}{|l} 
Sig. (1-tailed) \\
\end{tabular} & .392 & .167 & .392 & .004 & .023 & .025 & .177 & .255 & .454 & .177 & .308 & .019 \\
\hline & & $\mathrm{N}$ & 56 & 55 & 54 & 56 & 56 & 56 & 56 & 56 & 55 & 56 & 56 & 56 \\
\hline & Difficulties in & \begin{tabular}{|l|} 
Correlation Coefficient \\
\end{tabular} & .108 & .116 & .002 & $.336^{* \prime}$ & $.238^{*}$ & $-.227^{\star}$ & .064 & $.258^{*}$ & .181 & 214 & .154 & $.259^{\circ}$ \\
\hline & Managing / & Sig. (1-tailed) & .214 & .199 & .494 & .006 & .038 & .046 & .320 & .028 & .094 & .057 & .129 & .027 \\
\hline & Controlling RTP & $\mathrm{N}$ & 56 & 55 & 54 & 56 & 56 & 56 & 56 & 56 & 55 & 56 & 56 & 56 \\
\hline & Additional cost & \begin{tabular}{|l|} 
Correlation Coefficient \\
\end{tabular} & -.032 & .190 & .053 & $.337^{\prime \prime}$ & $.270^{\circ}$ & $-.249^{*}$ & -.055 & $.294^{*}$ & .195 & .201 & .111 & .168 \\
\hline & $\begin{array}{l}\text { Required for } \\
\text { Managing and }\end{array}$ & \begin{tabular}{|l} 
Sig. (1-tailed) \\
\end{tabular} & .407 & .082 & .352 & .006 & .022 & .032 & .344 & .014 & .077 & .069 & .208 & .107 \\
\hline & Controlling RTP & $\mathrm{N}$ & 56 & 55 & 54 & 56 & 56 & 56 & 56 & 56 & 55 & 56 & 56 & 56 \\
\hline
\end{tabular}


Table 12: Small effect size correlation of barriers to RTP and business performance

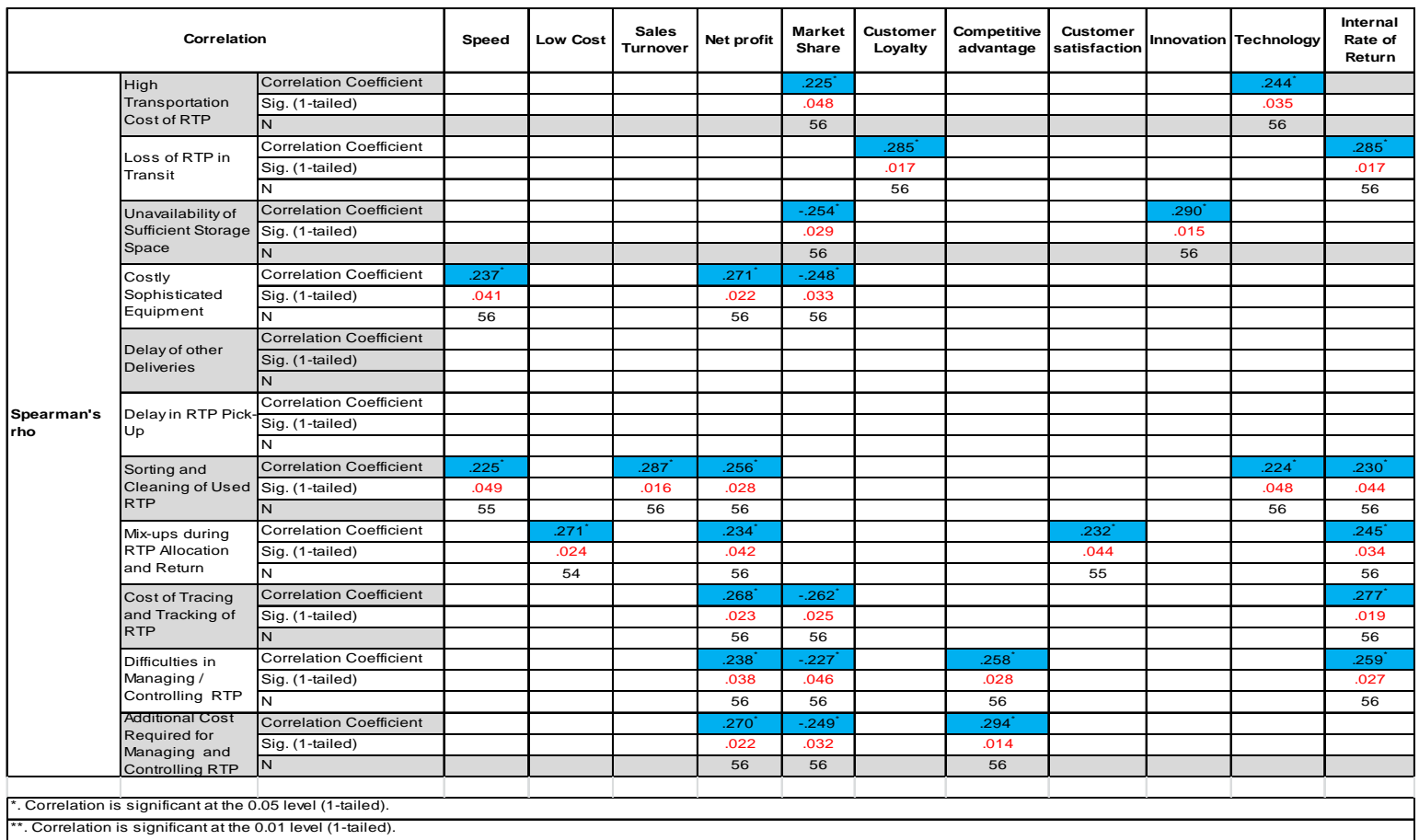

As shown in Table 12, each of the identified barriers has a small effect size correlation with most of the performance measures, which can be considered as weak relationships. For instance, high transportation cost of RTP has a small effect size correlation with market share and technology. Likewise, loss of RTP in transit holds a small effect size correlation with customer loyalty, and internal rate of return. Unavailability of sufficient storage space also retains a small effect size relationship with market share, competitive advantage and innovation. 
Table 13: Moderate effect-size correlation of barriers to RTP and business performance

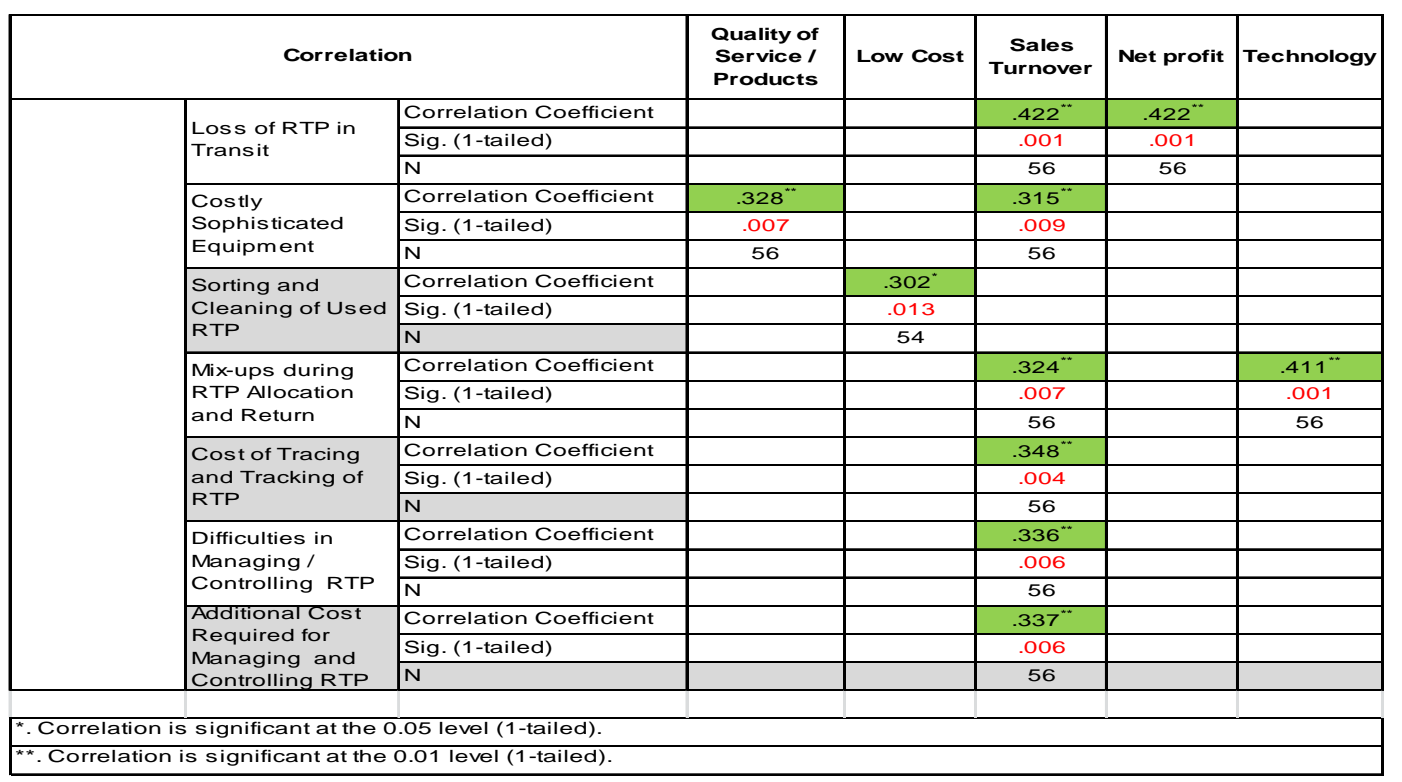

From Table 13 it can be construed that some of the barriers hold medium effect sizes with some of the performance measures, and this implies moderate relationships. For instance, loss of RTP in transit is interpreted to lessen a company's sales turnover and net profit moderately while costly sophisticated equipment is translated to diminish the quality of service / products and sales turnover moderately. Therefore, it can be established statistically that barriers to RTP deteriorate business performance.

\section{Conclusion}

This paper developed and conceptualised RTP as an environmental technology and a resource. It developed and tested a model that explained the usage of returnable transport packaging in RL using natural resource based view (NRBV) (Hart, 1995; Hart and Dowell, 2010). In particular, we analysed the drivers, the barriers to the usage of RTP and its cost-effectiveness, as well as its impact on business performance. Although NRBV has been used broadly to clarify the importance of capabilities in achieving sustainable competitive advantage (Vachon and Klassen, 2007), we have used it specifically to explain RTP implementation advantage in achieving environmental stewardship while conferring sustained economic performance and a socially responsible status on adoptee organisations.

The majority of firms sampled in Nigeria and South Africa have adopted the usage of RTP in their businesses. This is in contrast to the current belief that 
RL in developing countries is in its infancy (Sarkis et al., 2011; Zhang et al., 2011). Furthermore, there is increasing recognition and willingness to embrace RTP which is not matched by actual adoption due to financial constraints, especially amongst the SMEs. We have shown statistically that the size of the company as defined by annual turnover does not moderate the range of barriers to the use of RTP. This implies that both SMEs and large organisations face the same level of challenges when adopting RTP, thus highlighting the enormity of challenges confronting SMEs relative to the large and more resourceful organisations. These SMEs would benefit from financial support from large enterprises and governments in order to improve compliance with environmental regulations via the adoption of RTP.

Also, our findings corroborate that of Shaik and Abdul-Kaber (2013) where financial constraints was cited as a barrier to adoption in their studies of RTP implementation based on data drawn from developed countries. The barriers to RTP impacts the usage of RTP by weakening its business performance advantage. There is the need therefore for individual companies in to work collaboratively with logistics provider companies so as to abrogate some of these barriers (if not all) while improving the management and control of the usage of RTP in their organizations. This will not only eradicate the barriers, but will also develop mutual relationships across the supply chain of organizations concerned.

The relationship between the drivers and level of adoption of RTP are in two categories of those with low correlation and those with moderate correlation. Those drivers with moderate correlations include environmental, economic, social and operational benefits when adopting RTP. That is RTP adoption is largely a 'sustainability facing' initiative. Whilst adoption has a high level of positive impacts on measures of organisational performance, the measures are impacted upon at varying degrees.

In future research, there is the need to investigate the roles and types of products or supply chains within which the packages are used. This could then be extended to examine the effect of product status across the supply chain - that is, those products that are already shipped, to be shipped and will not be shipped in RTP. The focus of current study was Nigeria and South Africa, but future comparative studies of the developing countries and developed ones are necessary to test the influence of environmental awareness differentials across the two divide. 


\section{References:}

Abdallah, T., Diabat, A., \& Simchi-Levi, D. (2012) Sustainable supply chain design: a closed-loop formulation and sensitivity analysis. Production Planning \& Control: The Management of Operations 23(2-3), 120-133.

Abdulrahman, M. D., Gunasekaran, A., \& Subramanian, N. (2014). Critical Barriers in Implementing Reverse Logistics in the Chinese Manufacturing Sectors. International Journal of Production Economics 147 (Part B), 460-471.

Aitken, J., \& Harrison, A. (2013). Supply Governance Structures for Reverse Logistics Systems. International Journal of Operations \& Production Management 33(6), 745-764.

Amienyo, D. and Azapagic, A.(2016) Life cycle environmental impacts and costs of beer production and consumption in the UK, The International Journal of Life Cycle Assessment, 21 (4), pp 492-509

Ballou, R. H. (2004). Business logistics/supply chain management: planning, organizing, and controlling the supply chain. 5th ed., Prentice Hall.

Barney, J. (1991). Firm resources and sustained competitive advantage. Journal of Management 17(1), 99-120.

Bell, J.E., Autry, C.W., Mollenkopf, D.A., \& Thornton, L.M. (2012). A natural resource scarcity typology: theoretical foundations and strategic implications for supply chain management. Journal of Business Logistics, 33(2), 158-166.

Bernon, M., Rossi, S., \& Cullen, J. (2011). Retail reverse logistics: a call and grounding framework for research. International Journal of Physical Distribution \& Logistics Management, 41(5), 484-510.

Bouzon, M., Spricigo, R., Rodriguez, C.M.T., de Queiroz, A., \& Miguel, P.A. (2015). Reverse logistics drivers: empirical evidence from a case study in an emerging economy. Production Planning \& Control: The Management of Operations, DOI: 10.1080/09537287.2015.1049239.

Breen, L., (2006). Give me back my empties or else! A preliminary analysis of customer compliance in reverse logistics practices (UK). Management Research News, 29(9), pp. 532-551.

Burns, R.P., \& Burns, R. (2008). Business research methods and statistics using SPSS. Sage publications. 
Chan, K. (2007). A pro-active and collaborative approach to reverse logisticsa case study. Production Planning \& Control: The Management of Operations 18(4), 350-360.

Cohen, J. (1992). A power primer. Psychological bulletin 112(1), 155.

Day, G. (1994). The capabilities of market-driven organizations. Journal of Marketing 58(4), 37-52.

De Leeuw, E.D. (2005). To mix or not to mix data collection modes in surveys. Journal of Official Statistics 21(2), 233.

Dillman, D. (2000). Elements of the Tailored Design Method. Wiley, New York

Dowlatshahi, S. (2012). A framework for the role of warehousing in reverse logistics. International Journal of Production Research, 50(5), 1265-1277.

Europa (nd). 'Small and medium-sized enterprises (SMEs) Available at: http://ec.europa.eu/enterprise/policies/sme/index_en.htm Accessed 16 August, 2014.

Flynn, B.B., Sakakibara, S., Schroeder, R.G., Bates, K.A., \& Flynn, E.J., (1990). Empirical research methods in operations management. Journal of Operations Management 9(2), 250-284.

Forza, C., (2002). Survey research in operations management: a processbased perspective. International Journal of Operations \& Production Management 22(2), 152-194.

Fritz, M., \& Schieffer, G., (2009). Tracking, tracing, and business process interests in food commodities: A multi-level decision complexity. International Journal of Production Economics 117(2), 317-329.

Garetti, M., \& Taisch, M. (2012). Sustainable manufacturing: trends and research challenges. Production Planning and Control: the management of operations 23(2-3), 83-104.

Guarnieri, P., Sobreiro, V.A., Nagano, M.C., \& Serano, A. (2015). The challenge of selecting and evaluating third-party reverse logistics providers in a multicriteria perspective: a Brazilian case. Journal of Cleaner Production 96, 209-219.

Guide, V. D. R., Jr., \& Van Wassenhove, L. N. (2009). The Evolution of ClosedLoop Supply Chain Research. Operations Research 57(1), 10-18.

Hallgren, M., Olhager, J., \& Schoeder, R.G. (2010). A hybrid model of competitive capabilities. International Journal of Operations \& Production Management, 31(5), 511-526. 
Hart, S., \& Dowell, G. (2010). A natural-resource-based view of the firm: Fifteen years after, Journal of Management 37(5), 1464-1479.

Hart, S.L. (1995). A natural-resource-based view of the firm. Academy of Management Review 20(4), 986-1014.

Hellström, D., \& Saghir, M., 2007. Packaging and logistics interactions in retail supply chains. Packaging technology and science, 20(3), 197-216.

Hellström, D., \& Johansson, O. (2010). The impact of control strategies on the management of returnable transport items. Transportation Research Part E: Logistics and Transportation Review 46(6), 1128-1139.

Huang, Y., Jim, Y., \& Rahman, S. (2012). The task environment, resource commitment and reverse logistics performance: evidence from the Taiwanese high-tech sector. Production Planning and Control 23, 851-863.

Ilic, A., Ng, J.W., Bowman, P., \& Staake, T., (2009). The value of RFID for RTI management. Electronic Markets 19(2-3), 125-135.

Jayaraman, V., Ross, A.D., \& Agarwal, A., (2008). Role of information technology and collaboration in reverse logistics supply chains. International Journal of Logistics: Research and Applications, 11(6), 409-425.

Johansson, O., \& Hellström, D., (2007). The effect of asset visibility on managing returnable transport items. International Journal of Physical Distribution \& Logistics Management, 37(10), 799-815.

Karia, N., \& Wong, C.Y. (2013). The impact of logistic resources on performance: a survey of Malaysian logistics service providers. Production Planning \& Control 24(7), 589-606.

Klassen, R.D., \& Whybark, D.C. (1999). The impact of environmental technologies on manufacturing performance. Academy of Management Journal, 42(6), 599-615.

Kroon, L., \& Vrijens, G., (1995). Returnable containers: an example of reverse logistics. International Journal of Physical Distribution \& Logistics Management 25(2), 56-68.

Lacerda, L., (2002). Logística reversa: uma visão sobre os conceitos básicos e as práticas operacionais. Centro de Estudos em Logistica-COPPEAD, pp. 3.

Lambert, S., Riopel, D., \& Abdul-Kader, W. (2011). A reverse logistics decisions conceptual framework. Computers \& Industrial Engineering, 61(3), 561-581. 
Maleki, R.A., \& Reimche, J., (2011). Managing Returnable Containers Logistics-A Case Study Part I-Physical and Information Flow Analysis. International Journal of Engineering Business Management 3(2), 1-8.

Nicolaou, I.E., Evangelinos, K.I., \& Allan, S. (2013). A reverse logistics social responsibility evaluation framework based on the triple bottom line approach. Journal of Cleaner Production 56, 173-184.

Pallant, J. (2010). SPSS survival manual: A step by step guide to data analysis using SP. Open University Press.

Perunovic, Z., Mefford, R., \& Christoffersen, M. (2012). Impact of Information Technology on Vendor Objectives, Capabilities, and Competences in Contract Electronic Manufacturing. International Journal Production Economics 139(1), 207-219.

Rogers, D. S., \& Tibben-Lembke, R.S. (1998). Going Backwards: Reverse Logistics Trends and Practices. Reno, NV: Reverse Logistics Executive Council.

Rogers, D.S., \& Tibben-Lembke, R. (2001). An examination of reverse logistics practices. Journal of Business Logistics 22(2), 129-148.

Reusable Packaging Association (RPA) (2016). What is Reusable Packaging? Retrieved January, 102016 from http://reusables.org/choosereusables/what-is-reusable-packaging.

Saghir, M. (2004). The concept of packaging logistics, Proceedings of the Fifteenth Annual POM Conference, Cancun, April 30-May 32004.

Sarkis, J., Zhu, Q., \& Lai, K.H. (2011). An Organizational Theoretic Review of Green Supply Chain Management Literature. International Journal of Production Economics 130(1), 1-15.

Shaharudin, M. R., Zailani, S., \& Tan. K.C. (2015). Barriers to Product Returns and Recovery Management in a Developing Country: Investigation Using Multiple Methods. Journal of Cleaner Production 96(1), 220-232.

Shaik, M.N., \& Adul-Kader, W. (2013). Transportation in Reverse Logistics Enterprise: A Comprehensive Performance Measurement Methodology. Production Planning \& Control 24 (6), 495-510.

Shamsuzzoha, A., \& Helo, P.T. (2011). Real-time tracking and tracing system: Potentials for the logistics network, Proceedings of the 2011 international conference on industrial engineering and operations management 2011. 
Shi, V.G., Koh, L.SC, Baldwin, J., \& Cucchiella, F. (2012). Natural resource based green supply chain management. Supply Chain Management: an International Journal 17(1), 54-67.

Silva, D. A.L., Santos, G.W., Sevegnani, T.B., \& Truzzi, O.M.S. (2013). Comparison of disposable and returnable packaging: a case study of reverse logistics in Brazil. Journal of Cleaner Production 47, 377-387.

Sohrabpour, V., Hellström, D., \& Jahre, M. (2012). Packaging in developing countries: identifying supply chain needs. Journal of Humanitarian Logistics and Supply Chain Management 2(2), 183-205

Srivastava, P. (1995). Environmental technologies and competitive advantages. Strategic Management Journal, 16(summer), 183-200.

Stefansson, G., \& Tilanus, B. (2001). Tracking and tracing: principles and practice. International Journal of Services Technology and Management 2(3), 187-206.

Tabachnik, B.G., \& Fidell, L.S. (2001). Using multivariate statistics. Pearson Publications.

Thode, H.C. (2002). Testing for normality. CRC Press.

Twede, D., \& Clarke, R. (2004). Supply chain issues in reusable packaging. Journal of Marketing Channels 12(1), 7-26.

Vachon, S., \& Klassen, R.D. (2007). Supply chain management and environmental technologies: the role of integration. International Journal of Production Research, 45(2), 401-423.

Vachon, S., \& Klassen, R.D. (2008). Environmental management and manufacturing performance: The role of collaboration in the supply chain. International Journal of Production Economics 111(2), 299-315.

Wernerfelt, B. (1995), The resource-based view of the firm: Ten years after, Strategic management journal, 16 (3), 171-174

Wilson, J., (2014). Essentials of business research: A guide to doing your research project. Sage.

Wu, H., \& Dunn, S.C. (1995). Environmentally responsible logistics systems. International Journal of Physical Distribution \& Logistics Management, 25(2), 20-38.

Xie, M., Bai, W., Lu Bai, L., Sun, X., Lu, Q., Yan, D., and Qiao, Q. (2016) Life cycle assessment of the recycling of Al-PE (a laminated foil made from 
polyethylene and aluminum foil) composite packaging waste, Journal of Cleaner Production, 112 (5), 4430-4434

Yun, G.W., \& Trumbo, C.W. (2000). Comparative Response to a Survey Executed by Post, E-mail, \& Web Form. Journal of Computer-Mediated Communication, 6(1), 0-0.

Zhang, T., Chu, J., Wang, X., Liu, X., \& Cui, P. (2011). Development Pattern and Enhancing System of Automotive Components Remanufacturing Industry in China. Resources, Conservation and Recycling 55(6), 613-622.

\section{APPENDIX : (Questionnaire)}

\section{Part A: General company information}

1. Name of

Company.

2. Address of Company

3. Company's telephone number.

4. Company's email.

5. Company's year of establishment 
6. Name

(optional).....

7. Designation

of respondent.

8. What is your company's average annual expenditure (kindly tick the closest option that applies)

<R91.5m $\square \quad$ R91.5m- R366m $\square$ R384.3m- R915m $\square$ R933.3m-
R1830m $\square$ R1830m $\square$

9. What is your company's average annual turnover (kindly tick the closest option that applies)

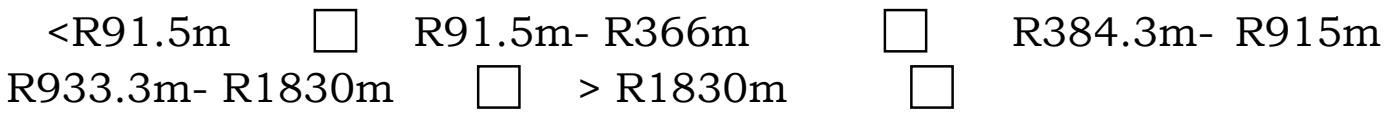

10. What is the total number of employees in your company?

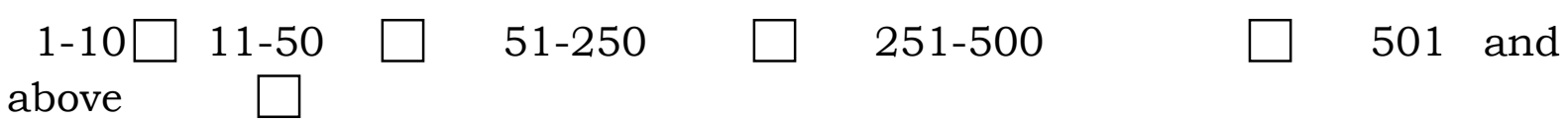


11. In which of the following channel positions do you operate? Check all that apply.

\section{Channel positions}

Manufacturer

Wholesaler

Retailer

Service
Provider
Tick

:......................................)
Logistics

(Please

specify

12. What is your company's major line of product? Please tick all that apply

\section{Line of products and activities \\ Tick}

Pharmaceutical products and beauty Aids

Perishable and non-perishable foods

Drinks and beverages

Fruits and vegetables

Groceries

Cooking gas

Automobile and automotive assembly, parts, components, accessories

Electrical and electronics equipment and components

Chemical products, allied products 
Furniture, home Furnishings and equipment

Construction products and building materials

Hospital, industrial, agricultural equipment and components

Supply and/or rental of equipment

Transport and/or storage

Consulting

Telecommunication

Clothing / apparel

Government

Catering

Aircraft and ship-building assembly, components, accessories, et cetera.

Other product line/ business activities (please specify)...............................

13. Has your company adopted the usage of Reusable Transport Packaging Items in Reverse Logistics? If yes please go to part $\mathrm{C}$ else go to part $\mathrm{B}$

\section{Part B: Single-use Transport Packaging System/ Reusable Transport Packaging Items}

14. Please indicate by ticking the type(s) of Transport Packaging system in use in your company

\section{Single-use transport packaging \\ Tick}

Corrugated containers 
Corrugated cardboard

Expendable packaging

Non-recyclable wax-coated corrugated boxes

Shipping containers with no lids

Bulk bags

Others (please specify)

15. What are the challenges faced by your organization in replacing the single-use transport packaging with Reusable Transport Packaging Items? Please tick all that apply

\section{Challenges}

Tick

Capital investment

Cost for Tracking and Accounting

Lack of governmental/law enforcement

Logistics and Warehousing

Transportation vs. Packaging

Others

(please

specify)

16. Will your company consider replacing single-use transport packaging with Reusable Transport Packaging Items in the near future?

Absolutely Yes $\square$ May be $\quad \square \quad$ May be no

Absolutely No 
17. If 'MAY BE NOT / ABSOLUTELY NO'; what factors would facilitate your company to consider the replacement of single-use transport packaging with Reusable Transport Packaging?

\section{Part C: Reusable Transport Packaging Items}

\section{Commonly used Reusable Transport Packaging Items:}

19. Please indicate by ticking the type(s) of Reusable Transport Packaging Items currently in use in your company

Types of Reusable Transport Packaging Items

\section{Tick}

Crates

Trolleys

Cases

Plastic pallets collar

Bulk containers

Plastic storage tanks

Carts

Reusable plastic pails

Trolleys 
Trays

Barrels

Plastic boxes

Plywood cases

Flight cases

Steel racks

Roll cages

Tote bins

Pallet pooling

Others (please specify)

20. Have the restraints of single-use transport packaging been concealed by Reusable Transport Packaging Items in your company? YES

$\mathrm{NO}$

21. How did your company get informed about Reusable Transport Packaging Items?

\section{Media}

\section{Tick}

Government

Reusable Transport Packaging

Items manufacturer

Trade Union Association (please specify) 
Customers

Consultants

Others (please specify)

22. The usage of Reusable Transport Packaging Items in your company has been influenced by one or more factors. Please tick all appropriate boxes as applicable to your company.

Factors

Disagree
Agree Strongly Agree

Disagree Strongly

Government regulation<smiles>C1CCC1</smiles>

Environmental consideration<smiles>C1=CC=C1</smiles>

Economic benefits

Environmental benefits

Operational benefits

Social benefits

Competitive advantage

Advantages over Single-Use

Transport Packaging
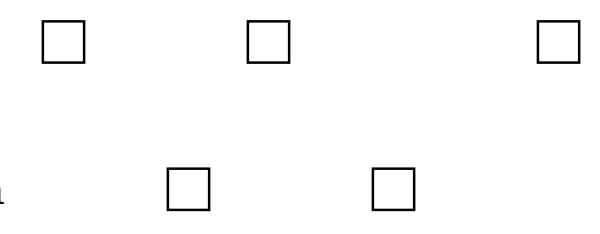

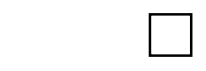

Neutral 
23. Rank the above factors in order of importance as making a decision to implement Reusable Transport Packaging Items in your company.

Factors

Little

Not

\section{Importance}

Government regulation

Important

Important

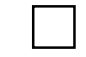

Very

Important

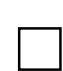

Environmental consideration<smiles>[CH]</smiles>

Economic benefits

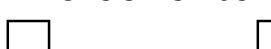

Environmental benefits
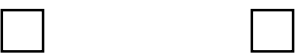

Operational benefits

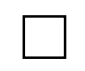

Social benefits

Competitive advantage

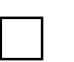

Advantages over Single-use

Transport Packaging

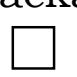

Others (Please specify)

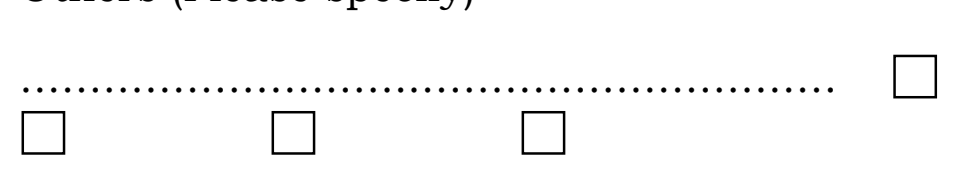

Cost effectiveness of Reusable Transport Packaging Items: 
24. How much has your company invested in Reusable Transport Packaging Items over the years?

$<\mathrm{R} 91,500 \quad \square=00$ - R183,000 $\square \quad \mathrm{R} 201,300-\mathrm{R} 457,500$
$\mathrm{R} 475,800-\mathrm{R} 915,000 \square \quad \mathrm{R} 915,500 \quad \square$

25. How long did it take your company to recover its investment on Reusable Transport Packaging Items?

\section{Durations}

Tick

Less than a year

1 year

2 years

3 years

4 years

5 years

Not yet

26. What is your annual loss rate on Reusable Transport Packaging Items?

Annual Loss Rate returned

$>\mathrm{R} 91,500$

$\mathrm{R} 73,200$ - R91,500

$\mathrm{R} 54,900$ - R73, 190

$\mathrm{R} 36,600$ - R54,890

$\mathrm{R} 19,300$ - R36,590

$\mathrm{R} 9,150-\mathrm{R} 18,290$ 
$<\mathrm{R} 9,150$

RO

27. Based on cost, how can you assess the usage of Reusable Transport Packaging Items in your company?

Very effective $\quad \square \quad$ Effective $\quad \square \quad$ Neutral $\quad \square \quad$ Less effective

\section{Potential benefits of Reusable Transport Packaging Items:}

28. Below are the measurable benefits of the Reusable Transport Packaging Items that pose as success factors for increasing the usage of Reusable Transport Packaging Items in reverse logistics, please tick the appropriate boxes as applicable to your company.

Factors Agree Strongly Agree

Neutral

Disagree

\section{Disagree Strongly}

Cost saving

Storage efficiency
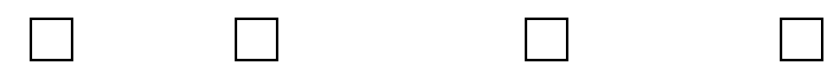

Staff (workers) safety

Less product damage
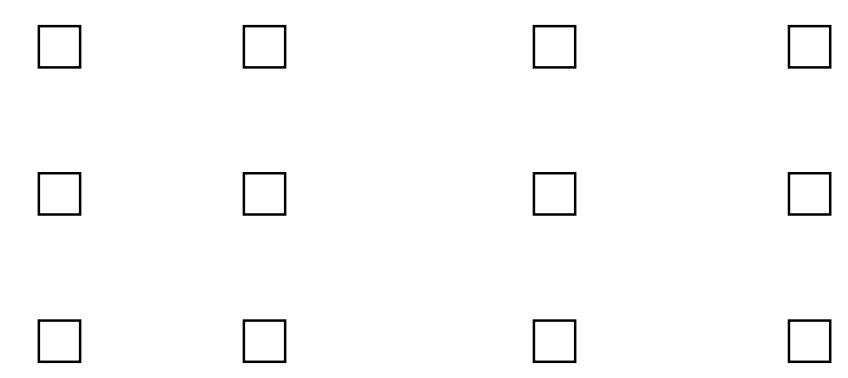

Operational efficiency
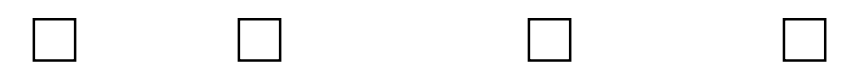
Improved inventory management

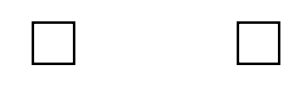

Provided better ergonomic design

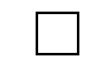

Increased handling efficiencies $\square$

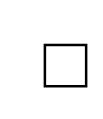

Avoided waste disposal costs $\square$

Agree Strongly Agree

Factors

Disagree

\section{Disagree Strongly}

Longer useful life
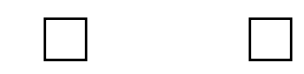

Easy to sanitize
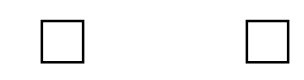

Customers' satisfaction
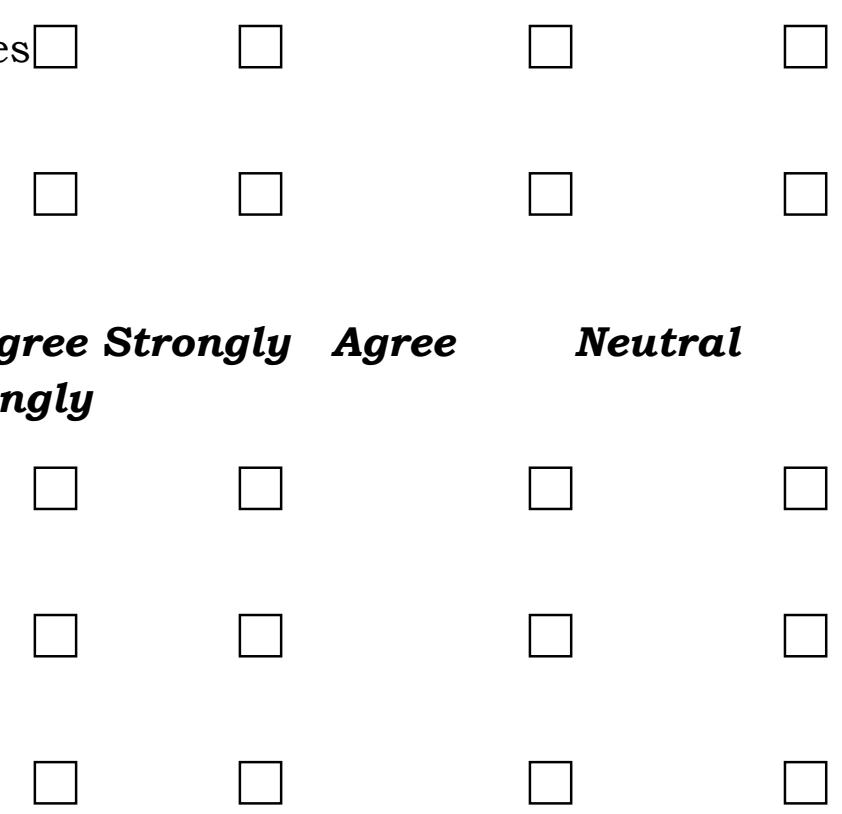

Neutral<smiles></smiles>

Environmental sustainability

Others (please specify)

i.

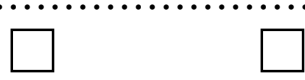

$\square$
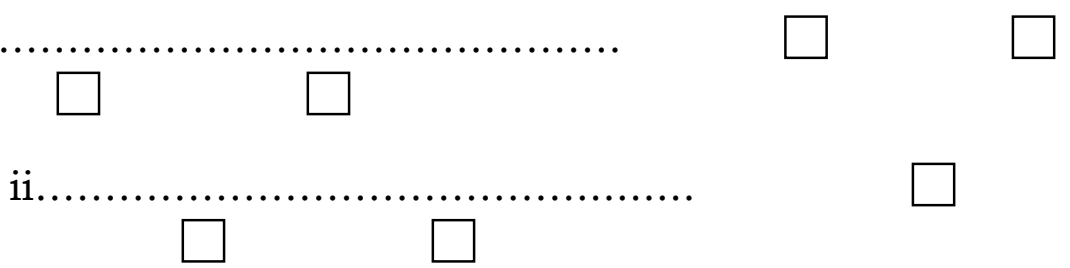

iii.

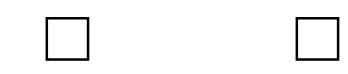

Managing and controlling Reusable Transport Packaging Items:

29. How does your company manage and control its Reusable Transport Packaging Items?

In-house

Third party such as distribution centres 
30. Has your company introduced/ initiated any structured management and control system to acquire an efficient and effective Reusable Transport Packaging Items distribution?

Certainly $\square \quad$ Somehow $\square \quad$ Not really $\square \quad$ Not yet

31. Please identify which of the three main types of Reusable Transport Packaging Items control strategies is use by your company. Please tick where applicable.

\section{Control strategy}

Tick

Switch-pool system

Transfer system

Depot system

32. Does your company include any form of visibility system in its Reusable Transport Packaging Items control strategy?

Yes

No

If YES, please state the visibility system use for controlling and monitoring Reusable Transport Packaging Items in your company

33. How long is the life cycle of a typical Reusable Transport Packaging Item in your company? Please tick that which apply to your company 
Less than a year

1 year

2 years

3 years

4 years

5 years

More than 5 years

34. What other measures has your company established for an efficient and effective management of Returnable Transport Packaging Items?

35. Have these measures been effective? Yes

$\square \quad$ Somehow No

36. If

no,

why?

\section{Possible challenges of Reusable Transport Packaging Items:}

37. Some challenges encountered in managing and controlling Reusable Transport Packaging Items are listed below, please tick the appropriate boxes as applicable to your company 
High transportation cost of Reusable

Transport Packaging Items

Loss of Reusable Transport Packaging

Items in transit

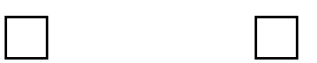

Unavailability of sufficient storage space

Costly sophisticated equipment

Delay of other deliveries as a result of same

time schedule of various packaging pick-ups

Delay in Reusable Transport Packaging

Items pick-up by suppliers

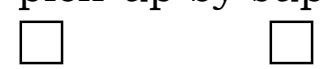

Sorting and cleaning of used Reusable

Transport Packaging Items

Mix-ups during Reusable Transport

Packaging Items' allocation and return

(in case of multiple suppliers)

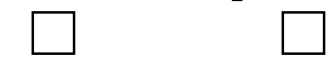

Cost of tracing and tracking of Reusable

Transport Packaging Items

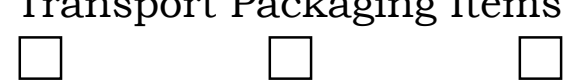

Difficulties in managing/controlling 
Reusable Transport Packaging Items
$\square \quad \square \quad \square$
Additional cost required for managing
and controlling Reusable Transport
Packaging Items

Assessing the usage of Reusable Transport Packaging Items:

38. How has the usage of Reusable Transport Packaging Items impacted on the following performance measures in your company?

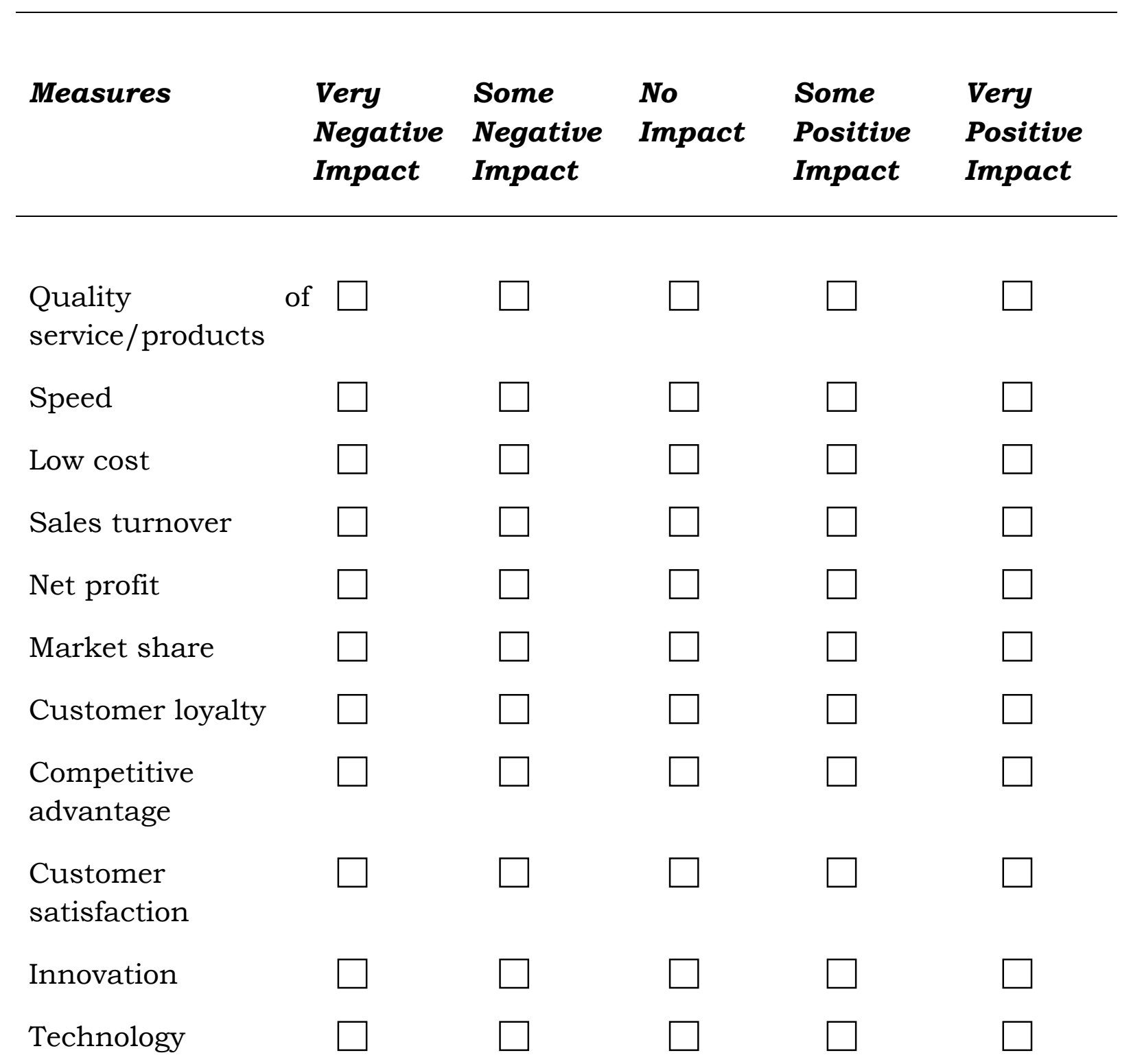




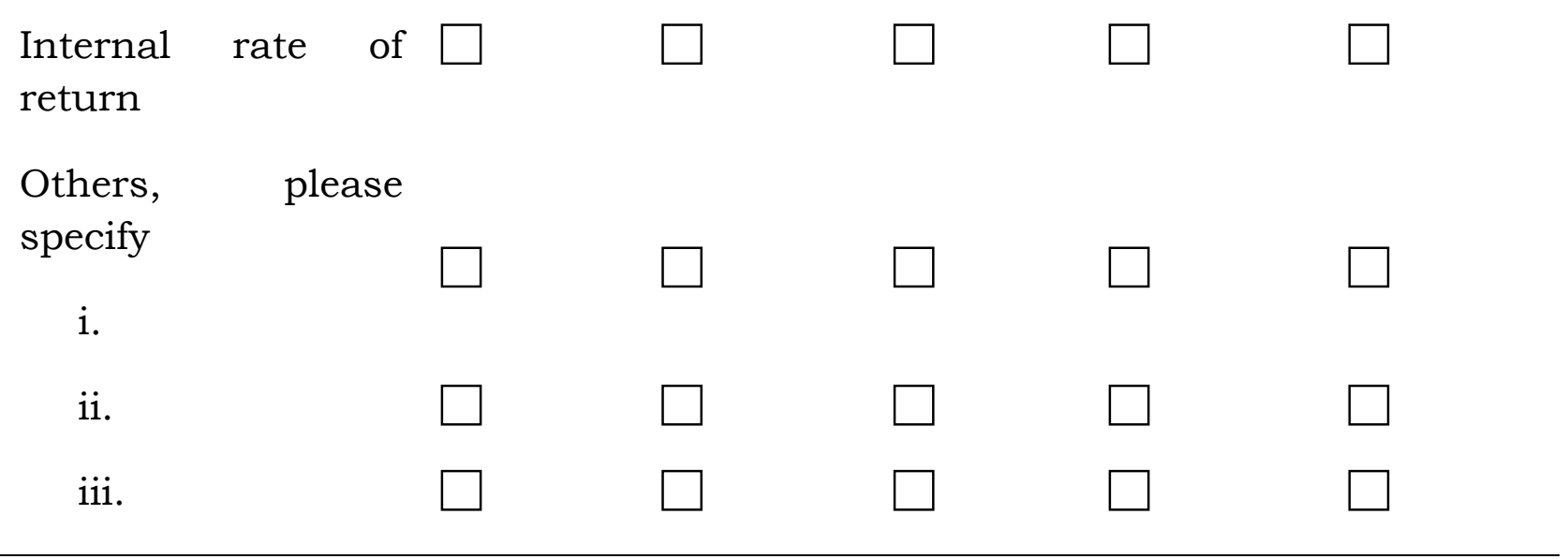

39. Do you think additional investments on Reusable Transport Packaging Items will boost your company's performance?

Definitely No Maybe not Not sure Maybe yes Definitely yes

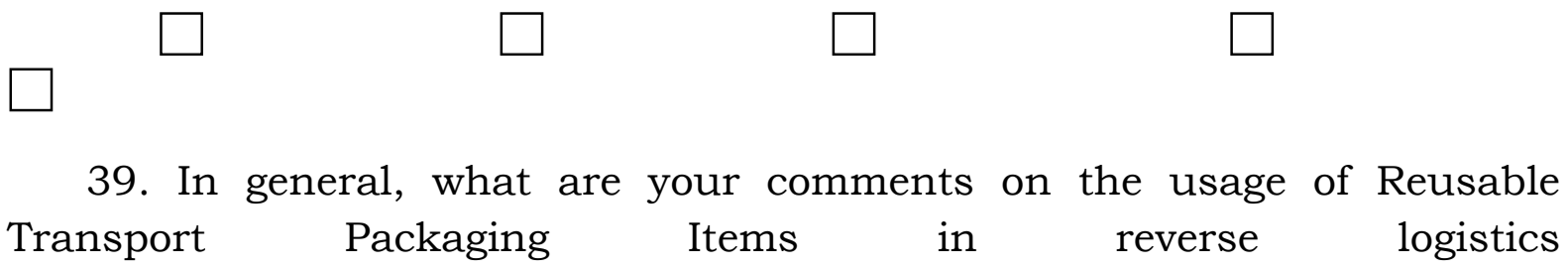




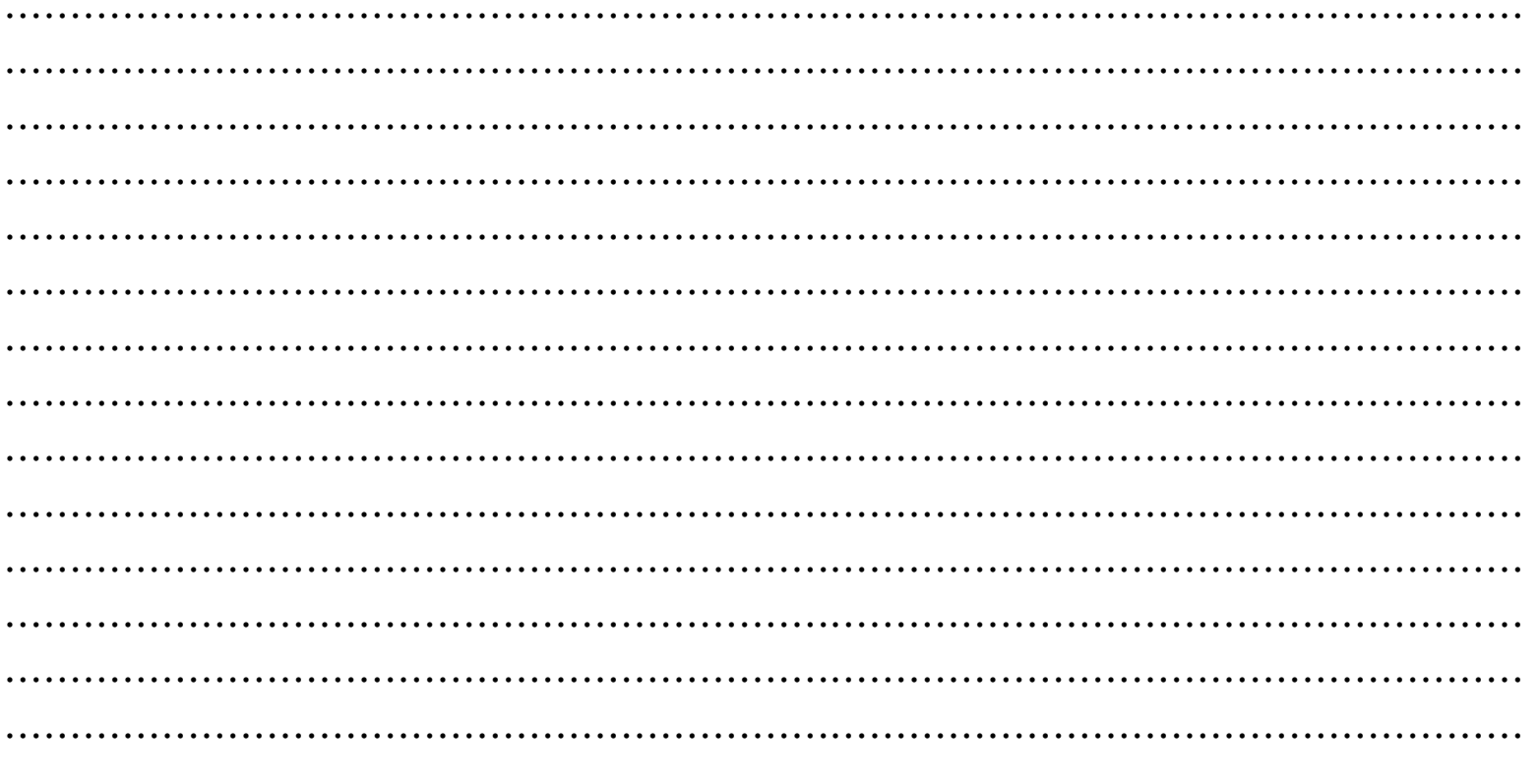

